\title{
Photo-protective compounds in red macroalgae from Brittany: Considerable diversity in mycosporine-like amino acids (MAAs)
}

\author{
Lalegerie Fanny ${ }^{1,}{ }^{*}$, Lajili Sirine ${ }^{1}$, Bedoux Gilles ${ }^{2}$, Taupin Laure ${ }^{2}$, Stiger-Pouvreau Valerie ${ }^{1}$, \\ Connan Solène ${ }^{1}$
}

\author{
1 Univ Brest, CNRS, IRD, Ifremer, LEMAR, F-29280, Plouzane, France \\ 2 Marine Biotechnology and Chemistry Laboratory (LBCM, EA 3884), University of South Brittany (UBS), \\ 56017, Vannes, France \\ *Corresponding author : Fanny Lalegerie, email address : fanny.lalegerie@univ-brest.fr
}

\begin{abstract}
:
To cope with the biotic and abiotic stresses experienced within their environment, marine macroalgae have developed certain defence mechanisms including the synthesis of photo-protective molecules against light and particularly harmful UV radiation. The aim of this study was to screen selected red algae, a highly diverse phylogenetic group, for the production of photo-protective molecules. The pigment content and composition (i.e. chlorophyll-a, phycobiliproteins and carotenoids) and the composition of mycosporine-like amino acids (MAAs) were studied in 40 species of red macroalgae collected in Brittany (France), at two distinct periods (i.e. February and July 2017). A high inter-specific variability was demonstrated in terms of pigment content and MAA composition. Twenty-three potential MAAs were detected by HPLC, and six were identified by LC-MS (i.e. shinorine, palythine, asterina-330, porphyra-334, usurijene and palythene). This is the first study to report on the composition of pigments and MAAs in a diverse group of red seaweeds from Brittany, including some species for which the MAA composition has never been studied before. Nevertheless, the results suggested that some species of red algae are more likely to cope with high levels of light radiation since those species such as Bostrychia scorpioides, Porphyra dioica, Gracilaria vermiculophylla and Vertebrata lanosa are living in environments exposed to higher levels of irradiation, and had various MAAs in addition to their photoprotective pigments.
\end{abstract}




\section{Graphical abstract}

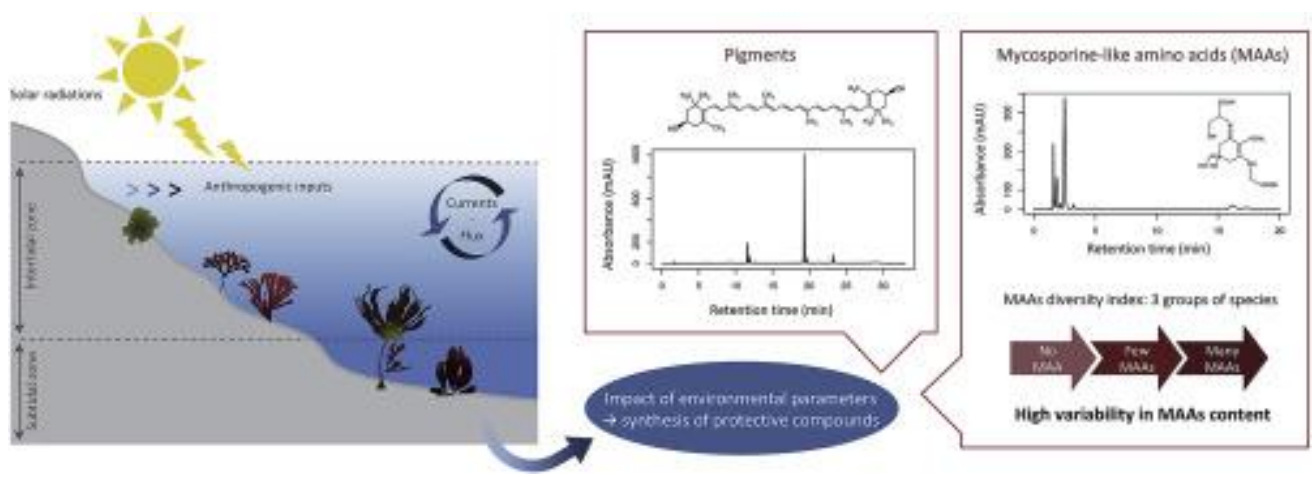

\section{Highlights}

Detection of 23 potential MAAs in 40 Rhodophyta species, including 6 already identified (shinorine, palythine, asterina-330, porphyra-334, usurijene, palythene). First report on the MAAs composition for some red seaweeds. High variability in MAAs content and composition between the different species, with no link with phylogeny, morphology, position on the shore or sampling site. A MAAs extraction method using $70 \%$ ethanol being less toxic than conventional methanol, and giving potential valorisable extracts.

Keywords : Algae, Diversity, HPLC, MAAs, Metabolites, Photo-protection, Pigments, Rhodophyta, Screening 


\section{Introduction}

Macroalgae are known to play a key role in coastal ecosystems as being at the basis of the food web and providing refugium for many animal species (Lüning, 1990). In particular, seaweeds produce diverse compounds under natural conditions, which could potentially be used in health, cosmetic, or food sectors (Holdt and Kraan, 2011; Stengel et al., 2011; Stiger-Pouvreau and Guérard, 2018; Surget et al., 2017). However, both the concentration and composition of these bioactive compounds can fluctuate within individuals, with their habitat and with season. In the context of climate change, the environmental parameters impacting particularly intertidal seaweeds are in a state of flux. To cope with changing environmental conditions, seaweeds have developed particular adaptive, metabolic responses and are thus able to resist and adapt to different abiotic stresses (Davison and Pearson, 1996; Gantt, 1990).

Irradiance is one of the factors which can change over the intertidal range in coastal areas, in term of quantity and quality because it varies during the day and with the tide, the turbidity of the water, the climate, the depth or seasons (Sagert et al., 1997). Light is also very important for seaweeds as algae are photosynthetic organisms (Gantt, 1990; Lobban and Harrison, 1994) with some living in the intertidal zone and thus exposed directly to the sunlight during emersion phases. One of the consequences of climate change is the amount of ultraviolet (UV) radiation reaching the Earth's surface (Bischof et al., 2006; Thomas et al., 2012). UV radiations are notably at the origin of DNA alterations, the synthesis of reactive oxygen species (ROS) and, in seaweeds, the photo-inhibition mechanism or the degradation of photosynthetic pigments (Karentz, 2001; Karsten, 2008; Van de Poll et al., 2001). However, due to human activities and 
ozone depletion, the protective filter that constitutes the atmosphere gradually loses its

50

effectiveness, which means that the amount of UV to which the organisms are exposed tends to increase (Carreto et al., 2018; McKenzie et al., 2007). Although some authors agree that the ozone layer will probably not fully recover before several decades, the hole in this layer would be resorbing at mid-latitudes due to the implementation of some policies tending to reduce greenhouse gas emissions, but this would not be the case at high latitudes and the evolution of the UV level remains complex (McKenzie et al., 2011; Wilmouth et al., 2018).

$$
\text { Different types of macroalgae have developed various strategies to protect }
$$

themselves from harmful UV radiation. These include the synthesis of photo-protective molecules (Bhatia et al., 2011; Le Lann et al. 2016; Rastogi et al., 2010; Sinha et al., 2007). Among the algal photo-protective compounds, this study focuses on pigments and mycosporine-like amino acids (MAAs), synthesized by red algae (Rhodophyta). MAAs were discovered in 1965 in the terrestrial fungus Ascochyta pisi (Leach, 1965). Since then, the presence of MAAs has been demonstrated in a wide range of marine organisms from bacteria to fish (Bandaranayake, 1998; La Barre et al., 2014; Rosic et al., 2015), including different species of algae (Bedoux et al., 2014; Sinha et al., 2007). MAAs are low molecular weight molecules $(<400 \mathrm{Da})$, soluble in water, with a high molar extinction coefficient (between 28,000 - 50,000 $\mathrm{M}^{-1} \cdot \mathrm{cm}^{-1}$ ) and a maximum of absorption $\left(\lambda_{\max }\right)$ between 310 - $362 \mathrm{~nm}$ (Rastogi et al., 2010). In addition, it has been demonstrated that red algae, which constitute a well-marked phylogenetic group, have the greatest diversity and the highest proportion of MAAs (Carreto and Carignan, 2011; Karentz, 2001; Sinha et al., 2007). Until now, about 20 MAAs have been identified in 
73 various red macroalgae (Sinha et al., 2007). However, as some recent studies have

74 shown (Briani et al., 2018; Hartmann et al., 2016), many MAAs have yet to be

75 identified. The major role of MAAs in photo-protection against UV radiation has

76 already been widely demonstrated (Bedoux et al., 2014; Huovinen et al., 2004; Singh et

77 al., 2008), and functionality could be linked to their individual structures (Wolley et al.,

78 2018). It appears that some MAAs may also have various functions such as anti-

79 oxidants (De la Coba et al., 2009; Torres et al., 2018; Wada et al., 2015), osmolytes,

80 nitrogen storage, or protective agents against desiccation or temperature variations

81 (Bhatia et al., 2011; Oren and Gunde-Cimerman, 2007).

82

Pigments are part of a second significant group of photo-protective compounds

84

85

86

87

88

89

90

91

92

93

94

95

96

in macroalgae. There are three main families of pigments: chlorophylls, carotenoids and phycobiliproteins (reviewed in Stengel et al., 2011). They do not all have a role in photo-protection, such as chlorophylls and phycobiliproteins which harvest light for photosynthesis. Among the chlorophylls, there is only chlorophyll- $a$ in red algae (Stengel et al., 2011). One characteristic of red algae is the presence of phycobiliproteins (reviewed by Dumay et al., 2014). These are "secondary pigments" which also capture solar energy and transfer it to chlorophyll $a$ for the photosynthesis; they are particularly effective under low light conditions (Gantt, 1990; Lobban and Harrison, 1994). There are 3 main groups of phycobiliproteins in the Rhodophyta: phycoerythrin $\left(\mathrm{PE}, \lambda_{\max }=540-570 \mathrm{~nm}\right.$ ) which provides their red colour, phycocyanin $\left(\mathrm{PC}, \lambda_{\max }=610-620 \mathrm{~nm}\right)$ and allophycocyanin $\left(\mathrm{APC}, \lambda_{\max }=650-655 \mathrm{~nm}\right)$ which both have a blueish hue (Dumay et al., 2014). Finally, there are two groups of carotenoids: carotenes ( $\alpha$-carotene, $\beta$-carotene in red algae) and xanthophylls (i.e. zeaxanthin, 
97 antheraxanthin, violaxanthin and lutein in red algae) which convey a yellowish

98 colouration. These last pigments have several physiological roles (Karsten, 2008;

99 Young and Frank, 1996): they take part in photosynthesis through light harvesting in

100 thylakoids (Hashimoto et al., 2016) but they also have an important role in photo-

101 protection (Mimuro and Akimoto, 2003). Indeed, they also may participate in the

102 dissipation of solar energy (Young et al., 1997) and to the de-activation of reactive

103 oxygen species (ROS) (Rastogi et al., 2010).

According to the nature, quality and quantity of photo-protective compounds, of macroalgae are then more or less sensitive to UV radiation (Davison and Pearson,

107 1996; Roleda et al., 2004). In this context, the aim of the present study was to

108 investigate the inter-specific variations in red algal photo-protective compounds within

109 a diverse, representative group of temperate and local red seaweeds. Thus, a screening

110 was carried out on a large number of red seaweeds sampled from the coast of Brittany

111 (France). In order to study the maximum number of species, seaweeds were sampled

112 during two distinctly different seasons, i.e. winter and summer, as some species occur

113 only during a part of the year. Candidate species for analysis were also collected from

114 the upper subtidal zone (i.e. emersed only at spring tides for maximum $1 \mathrm{~h}$; Ar Gall and

115 Le Duff, 2014) and along the intertidal zone (i.e. with different maximum emersion

116 times from $1 \mathrm{~h}$ in the lower intertidal zone to $12 \mathrm{~h}$ in the upper intertidal zone during 117 spring tides; Ar Gall and Le Duff, 2014). A MAA diversity index was determined for 118 each species, in order to compare and provide hierarchical comparisons within the red 119 macroalgae collected in this study. Moreover, in order to test the hypotheses of a 120 relationship between the diversity of MAAs and individual red algal taxonomy, various 
121 orders/families of red macroalgae were specifically targeted for collection.

122

\section{2. Materials and methods}

\section{$124 \quad 2.1$ Sampling sites}

125 Macroalgae were collected at low tides on four different sites in Brittany (France):

126 Porspoder $\left(48^{\circ} 28^{\prime} 58^{\prime}{ }^{\prime} \mathrm{N}-4^{\circ} 46^{\prime} 5^{\prime}, \mathrm{W}\right)$, Portsall $\left(48^{\circ} 33^{\prime} 53^{\prime}{ }^{\prime} \mathrm{N}-4^{\circ} 42^{\prime} 5^{\prime}\right.$ ' $\left.\mathrm{W}\right)$, Saint-Pabu $127\left(48^{\circ} 34^{\prime} 34^{\prime \prime} \mathrm{N}-4^{\circ} 38^{\prime} 45^{\prime \prime} \mathrm{W}\right)$ and Le Faou (48 $17^{\prime} 44^{\prime \prime} \mathrm{N}-4^{\circ} 10^{\prime} 56^{\prime}$ 'W). Portsall, 128 exposed North-West, is a sheltered and mainly rocky site, surrounded by sand and 129 intertidal pools. Despite its western exposure, Porspoder remains sheltered due to the 130 presence of two large rocky over-hangs. The site chosen at Saint-Pabu, was exposed to

131 the North; it is characterized by sandy dunes. Finally, Le Faou differs from the three 132 previous sites because a river flows there into the Bay of Brest, forming a sheltered but 133 muddy estuary at low tide. Two samplings periods were carried out: in February 134 (winter) and July (summer) 2017.

\subsection{Macroalgal samples}

137 Forty species of red macroalgae were collected across the four different sites: 21 species 138 were found both in winter and summer and 19 species were found on the shore only for 139 one season. All species belong to the class of Florideophyceae, except Porphyra dioica

140 (Bangiophyceae). These included species from different morpho-anatomical groups (i.e. 141 MAG, according to Steneck and Dethier, 1994): filamentous algae (MAG 2); corticated 142 or polysiphonous filaments algae (MAG 2.5); foliose algae (MAG 3); corticated foliose 143 algae (MAG 3.5); corticated algae (MAG 4); and articulated calcareous algae (MAG 6) 144 (Appendix 1). 
145 After collection, algal samples were brought back to the laboratory into sampling bags.

146 Samples were stored in a fridge and washed within 4 hours of sampling with filtered

147 seawater to remove residual sediments and salt; visible epiphytes were removed by

148 hand. Seaweeds were then stored in the freezer before being freeze-dried ( $\beta 1-8$ LD plus

149 Christ) and the entire thallus was milled into a fine powder (MM400 Retsch). The dried

150 powder was kept in darkness at room temperature until analyses.

151

152

2.3 Extraction and assay of chlorophyll-a and carotenoids

Pigments were extracted from $75 \mathrm{mg}$ dry weight (DW) of algal powder in

$154750 \mu \mathrm{L}$ of $90 \%$ acetone, according to Schmid and Stengel (2015). Two successive

155 extractions of 30 min and $4 \mathrm{~h}$ were carried out at $4{ }^{\circ} \mathrm{C}$, under magnetic agitation.

156 Samples were then centrifuged at 10,000 rpm for 5 min (miniSpin plus, Eppendorf), and

157 the supernatants combined and filtered for HPLC (High Pressure Liquid

158 Chromatography) analysis (Dionex Ultimate 3000, ThermoScientific). Pigments were

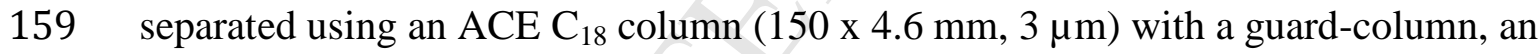

160 injection volume of $6 \mu \mathrm{L}$ and a run-time of 33 min per sample. Before injection, each

161 sample was automatically diluted $3 / 4$ with ammonium acetate buffer (0.5 M, pH 7.2).

162 Separation was achieved using a solvent gradient described in Table 1, delivered at a

163 flow rate of $1.0 \mathrm{~mL} \cdot \mathrm{min}^{-1}$. A photo-diode array detector (DAD3000, ThermoScientific)

164 was used for the detection of pigments at 435, 470 and $650 \mathrm{~nm}$. The identification and

165 quantification of each pigment was based on spectral comparisons and calibration using

166 commercial standards: chlorophyll $a$ (Sigma, USA), and $\alpha$-carotene, $\beta$-carotene, lutein,

167 zeaxanthin, antheraxanthin, violaxanthin (DHI, Denmark). Only peaks with an area

168 larger than $0.4 \mathrm{mAU}$.min for $\alpha$ - and $\beta$-carotenes and $1 \mathrm{mAU}$.min for the other pigments 
169 were considered in the analysis. HPLC data were collected using Chromeleon 0.7

170 software (Thermo Scientific Dionex, France).

171

172

173

174

175

176

177

178

179

180

181

182

183

184

185

186

187

188

189

190

191

\subsection{Extraction and assay of phycobiliproteins}

Tissue concentrations of phycoerythrin (PE) and phycocyanin (PC) were determined using a method adapted from Sun et al. (2009). Two successive extractions of $15 \mathrm{~min}$ at $4{ }^{\circ} \mathrm{C}$ were performed from $75 \mathrm{mg} \mathrm{DW}$ of algal powder, with $1.5 \mathrm{~mL}$ of phosphate buffer (0.1 M, pH 6.8). Subsequently, samples were centrifuged for $20 \mathrm{~min}$ at 10,000 rpm (miniSpin plus, Eppendorf) and supernatants were used to measure absorbances at 455, 565, 592, 618 and $645 \mathrm{~nm}$ using a spectrophotometer (POLARStar Omega, BMG LABTECH). The concentrations of PE and PC (mg.g $\left.\mathrm{g}^{-1} \mathrm{DW}\right)$ were estimated using the following equations from Beer and Eshel (1985):

$[\mathrm{PE}]=[(\mathrm{A} 565-\mathrm{A} 592)-(\mathrm{A} 455-\mathrm{A} 592) \times 0.20] \times 0.12$

$[\mathrm{PC}]=[(\mathrm{A} 618-\mathrm{A} 645)-(\mathrm{A} 592-\mathrm{A} 645) \times 0.51] \times 0.15$

\subsection{Mycosporine-like Amino Acids (MAAs) extraction and assay}

$20 \mathrm{mg}$ DW of finely ground algae were extracted for $2 \mathrm{~h}$ with $2 \mathrm{~mL}$ of $70 \%$ aqueous ethanol (v/v) at $45^{\circ} \mathrm{C}$ with magnetic stirring. After centrifugation (centrifuge 5810, Eppendorf) at 1,500 rpm for $10 \mathrm{~min}$, the supernatant was recovered. The pellet was re-extracted twice following the same procedure and the combined supernatants were evaporated to dryness under vacuum (miVac, Genevac, France) at $45^{\circ} \mathrm{C}$. The evaporated extracts were then stored at $-20{ }^{\circ} \mathrm{C}$ before analysis.

Prior to HPLC analysis, extracts were dissolved in $500 \mu \mathrm{L}$ of $2.5 \%$ aqueous methanol with $0.1 \%$ acetic acid, centrifuged for $5 \mathrm{~min}$ at 10,000 rpm (miniSpin plus, 
192 Eppendorf), and filtered through $0.2 \mu \mathrm{m}$-pore syringe filters. MAAs analyses were

193 performed using a Dionex Ultimate 3000 HPLC (Thermo Scientific, Germany)

194 equipped with a diode-array detector (DAD). MAA separation was performed using a

195 Zorbax Eclipse XDB $\mathrm{C}_{18}$ column, $5 \mu \mathrm{m}, 4.6 \times 250 \mathrm{~mm}$ (Agilent, USA) equipped with a

196 guard-column. For one analysis, $20 \mu \mathrm{L}$ of extract were injected and the operating

197 parameters were as follow: $0.1 \%$ acetic acid in Milli-Q water as the mobile phase; a

198 flow rate of $1 \mathrm{~mL} \cdot \mathrm{min}^{-1}$; a column temperature of $25 \pm 1^{\circ} \mathrm{C}$; an injector temperature of

$1995 \pm 1{ }^{\circ} \mathrm{C}$; a run time of $20 \mathrm{~min}$. MAAs were detected at $320,330,334$ and $360 \mathrm{~nm}$.

200 HPLC data were collected using Chromeleon 0.7 software (Thermo Scientific Dionex,

201 France). Individual peaks were identified by online absorption spectra and retention

202 time (Rt).

203

204

For identification, MAAs extracts were also analyzed by LC-MS using a LC-

205 ESI-Q-TOF-MS (Dionex, Ultimate 3000, Bruker, micrOTOF-QII) system (Bruker

206 Daltonik GmbH, Bremen, Germany). The same LC method was used, only the flow was

207 reduced to $0.5 \mathrm{~mL} \cdot \mathrm{min}^{-1}$. Source parameters were: positive mode; source temperature,

$208200{ }^{\circ} \mathrm{C}$; capillary voltage, $4.5 \mathrm{kV}$; nebulizer gas $\left(\mathrm{N}_{2}\right)$ at 2.8 bars and dry gas $\left(\mathrm{N}_{2}\right)$ at 12

209 L.min ${ }^{-1}$. Mass spectra acquisition was set at $0.5 \mathrm{~Hz}$ from $\mathrm{m} / \mathrm{Z} 50$ to 1000 . MS/MS

210 analyses were performed with a collision energy of $30 \mathrm{eV}$ and an isolation width of 2

$211 \mathrm{~m} / \mathrm{Z}$. All raw data were collected with Compass dataAnalysis Version 4.1. The

212 quantification of the identified MAAs was accomplished using their molar extinction

213 coefficients $\varepsilon$ at the wavelengths of maximum absorption, according to Pelillo et al.

214 (2004), and the molar extinction coefficient of Karsten et al. (1998b). For MAAs whose 
215 molecular structure has not yet been elucidated, their quantification was not established.

216 Each MAA was then numbered in the order in which it appeared during the run.

Finally, the diversity of MAAs within each seaweed species tested was

219 estimated by the development of a new index. The presence and absence of each MAA

220 for each species was coded in a table, as 0 or 1 respectively. A distance matrix was then

221 calculated by comparing species two by two using the following index:

$$
\text { Index }=\frac{M}{M+N}
$$

222 were ' $M$ ' is the number of matches between the two species (presence and absence) and 223 'N' the total number of MAAs which were present in only one of the two species. The 224 closer the index was to 1 , the more similar the two species were in terms of the composition of their MAAs. A species with many weak indices thus represented a specific composition. A dendrogram was made from this matrix with the $\mathrm{R}$ program $(\mathrm{R}$ 227 development core team, 2008) to represent species that had similar MAA compositions 228 (hclust with single method, hclust package). In order to highlight any links between the 229 composition of MAAs by algal species with their phylogeny, a phylogenetic analysis was performed using $r b c \mathrm{~L}$ and $\operatorname{coxl}$ genes sequences, as retrieved from GenBank

231 (Accession numbers for GenBank sequences are listed in Appendix 1 and are available 232 on https://www.ncbi.nlm.nih.gov). Sequences were aligned using the ClustalW 233 programme in the BioEdit alignment editor (Hall, 1999). A phylogenetic tree was built 234 using MEGA version 7 (Kumar et al., 2016), based on the Neighbor-Joining clustering method. Evolutionary distances were computed using the Maximum Composite

236 Likelihood. The tree was subjected to a bootstrap test (5000 replicates) to estimate 237 robustness at each branch (pvclust, pvclust package). 
240 All data were statistically analyzed with the R program ( $\mathrm{R}$ development core team,

241 2008). All extractions were performed in triplicate, and results expressed as average \pm

242 standard deviation (SD). Comparisons were carried out using a Student's t-test (2

243 samples) or an ANOVA (more than 2 samples). Beforehand, the conditions of

244 application were controlled using the Shapiro test for compliance with a normal

245 distribution, and the F-test or Bartlett's test for the homogeneity of variance (Dytham,

246 2011). The non-parametric Wilcoxon test (2 samples) or Scheirer-Ray-Hare test (SHR,

247 more than 2 samples) were used when at least one of the conditions of application was

248 not met (to replace the t-test or the ANOVA, respectively). If possible, when significant

249 results were highlighted, post-hoc tests (i.e. multiple comparisons) were performed: a

250 Tukey post-hoc test after an ANOVA (TukeyHSD), or a non-parametric post-hoc test

251 after a Sheirer-Ray test (kruskalmc, pirgmess package) (Dytham, 2011). Principal

252 Component Analysis (PCA) was carried out (package FactoMineR) to highlight species 253 which stood out.

\section{Results}

3.1 Pigments: chlorophyll a, carotenoids and phycobiliproteins

257 The chlorophyll $a$ content (Fig. 1) varied significantly among the analyzed red algal

258 species (SHR test, p-value < 0.0001). In some species, such as Mastocarpus stellatus or

259 Furcellaria lumbricalis, chlorophyll $a$ concentrations did not exceed $1 \mathrm{mg}^{-1} \mathrm{~g}^{-1} \mathrm{DW}$ -

260 whatever the season. However, Callithamnion tetragonum and Plumaria plumosa for

261 example contained in winter $8.60 \pm 0.26$ and $8.37 \pm 0.21 \mathrm{mg} \cdot \mathrm{g}^{-1} \mathrm{DW}$ of chlorophylle $a$, 
262 respectively. Moreover, a seasonal variability was demonstrated with chlorophyll $a$

263 concentrations decreasing in summer (SHR test, $\mathrm{p}$-value $=0.0040)$. For example,

264 Palmaria palmata contained $7.02 \pm 0.31 \mathrm{mg} \cdot \mathrm{g}^{-1} \mathrm{DW}$ of chlorophyll $a$ in February, and

$2651.50 \pm 0.27 \mathrm{mg} \cdot \mathrm{g}^{-1} \mathrm{DW}$ in July. Conversely, Bostrychia scorpioides was the only

266 species with a significantly increased concentration in summer (i.e. $5.44 \pm 0.43$, as

267 compared to $4.32 \pm 0.09 \mathrm{mg} \cdot \mathrm{g}^{-1} \mathrm{DW}$ in winter).

268 Similarly, total concentration of carotenoids changed with species (SHR test, p-value <

269 0.0001) (Fig. 2). For example, Chondrus crispus and F. lumbricalis contained less than

$270 \quad 0.2 \mathrm{mg} \cdot \mathrm{g}^{-1} \mathrm{DW}$ of carotenoids, whereas Vertebrata lanosa, Porphyra dioica or $B$.

271 scorpioides contained up to $0.78,0.84$ and $0.65 \mathrm{mg} \cdot \mathrm{g}^{-1} \mathrm{DW}$ of total carotenoids,

272 respectively. A difference in term of composition was also observed (Fig. 2): overall,

273 lutein was the most common carotenoid in 31 species out of 40 . However, the amount

274 of lutein remained low as compared to chlorophyll $a$, which constituted $90.1 \%$ on

275 average of the total liposoluble pigment content. Moreover, there was no seasonal

276 variation in the carotenoid composition as a whole, but the concentration was seen to

277 decrease in summer (SHR test, p-value =0.0012) (Fig. 2), except for V. lanosa in which

278 the concentration increased (e.g. $0.78 \pm 0.01$ and $0.66 \pm 0.04 \mathrm{mg} . \mathrm{g}^{-1} \mathrm{DW}$ in summer and

279 winter, respectively). Gigartina pistillata, Metacallophyllis laciniata and

280 Membranoptera alata did not contain any detectable levels of carotenoids in summer.

281 However, although there were seasonal variations in chlorophyll $a$ and overall

282 carotenoid amounts, the ratio of carotenoids / chlorophyll $a$ appeared to be constant

283 between both seasons (SHR test, $\mathrm{p}$-value $=0.4919)($ data not shown $)$. 
286 (Fig. 3). For example, Bornetia secundiflora and Membranoptera alata contained 27.39

$287 \pm 3.13$ and $19.67 \pm 0.15 \mathrm{mg} \cdot \mathrm{g}^{-1} \mathrm{DW}$ of PE in winter, respectively, whereas $C$. crispus,

288 Mastocarpus stellatus or V. lanosa contained less than $5.0 \mathrm{mg} \cdot \mathrm{g}^{-1} \mathrm{DW}$ (Fig. 3).

289 P. plumosa was more differentiated from the other species with high levels of PE in

290 both seasons $\left(23.18 \pm 0.49 \mathrm{mg} \cdot \mathrm{g}^{-1} \mathrm{DW}\right.$ in winter and $13.58 \pm 1.36 \mathrm{mg} \cdot \mathrm{g}^{-1} \mathrm{DW}$ in

291 summer). Moreover, it would appear that, on the whole, the PE content decreased in

292 summer (SHR test, p-value < 0.0001). Bostrychia scorpioides was the only species for

293 which the PE concentration really increased in summer $\left(6.62 \pm 0.22 \mathrm{mg} \cdot \mathrm{g}^{-1} \mathrm{DW}\right.$ in

294 summer, compared to $5.32 \pm 0.50 \mathrm{mg} \cdot \mathrm{g}^{-1} \mathrm{DW}$ in winter). The results were similar for

295 phycocyanin (data not shown).

296

297

A Principal Component Analysis (PCA) of all pigments (Fig. 4a, 4b) pointed out 298 six species: B. scorpioides, Porphyra dioica, V. lanosa, Gracilaria vermiculophylla,

299 Gracilaria gracilis and Plumaria plumosa. This last species contained the highest

300 concentration of chlorophyll $a$ and phycoerythrin. The five other species were the only

301 ones containing zeaxanthin with a concentration of $0.5 \mu \mathrm{g} \cdot \mathrm{g}^{-1} \mathrm{DW}$ or greater. G. gracilis

302 also contained antheraxanthin. Finally, the species belonging to similar MAG showed

303 different pigment content (chlorophyll $a$, carotenoids and phycoerythrin) and

304 composition. Moreover, no link between pigment composition of the red seaweeds

305 studied here and their phylogeny, morphology, position on the shore or sampling site

306 could be demonstrated. 
310 and Appendix 2), and six (i.e. shinorine, palythine, asterina-330, porphyra-334,

311 usujirene and palythene) were elucidated by LC-MS. The composition and

312 concentration of various MAAs showed a difference between the various species of red

313 macroalgae sampled in this study. These observations were independent of the sampling

314 season. Amongst the 21 species of algae commonly occurring in both seasons

315 considered, six did not contain any MAA (these included: F. lumbricalis,

316 Metacallophyllis laciniata, Polyides rotunda, Osmundea pinnatifida, Membranoptera

317 alata and Plumaria plumosa). For the eight species which could be collected only in

318 summer, no MAAs were detected in four and for those harvested only in winter, five did 319 not contain any detectable MAAs. At the same time, Mastocarpus stellatus contained a

320 high concentration of only shinorine (i.e. $3.12 \pm 0.26$ and $1.62 \pm 0.07 \mathrm{mg} \cdot \mathrm{g}^{-1} \mathrm{DW}$,

321 respectively in winter and in summer). One should note that three species, i.e. Palmaria

322 palmata, B. scorpioides and G. vermiculophylla, contained eight different MAAs,

323 visible as separate peaks on the chromatograms (data not shown). A chromatogram of

324 the MAAs analysed from P. palmata (Fig. 6) showed the presence of six identified

325 MAAs (i.e. shinorine, palythine, asterina-330, porphyra-334, usujirene and palythene)

326 and two other molecular structures that may correspond to MAAs. Moreover, some

327 unidentified MAAs were present in only one algal species, such as B. scorpioides,

328 which contained four unidentified (new) MAAs (i.e. MAA_4, MAA_13, MAA_18 and

329 MAA_23), G. pistillata which had MAA_14 and MAA_22, and V. lanosa MAA_1

330 (Fig. 5). 

among all sampled red macroalgae in this study. Indeed, with the exception of able to produce MAAs. Shinorine was found to be in sizeable quantities in M. stellatus, G. gracilis, and Ceramium nodulosum with $3.12 \pm 0.26,4.00 \pm 0.06$ and $1.92 \pm 0.11$ $\mathrm{mg} \cdot \mathrm{g}^{-1} \mathrm{DW}$, respectively for species harvested in winter (February). These amounts were approximately halved in July with $1.62 \pm 0.07,1.47 \pm 0.10$ and $0.86 \pm 0.06 \mathrm{mg} . \mathrm{g}^{-1}$ $\mathrm{DW}$, respectively for the same algae ( $\mathrm{t}$ test, $\mathrm{p}$-value $=0.0004)$. The next most common MAA was palythine which was found in 19 different species. p-value $=0.7804)$ and their composition was observed between both sampling periods in the different species (Fig. 5). However, some changes were noticed such as in $O$. pinnatifida with the presence of asterina-330, usujirene and palythene in those thalli collected in winter (February), but not in those collected in summer (July). The same was observed for G. pistillata with the presence of two new MAAs (i.e. MAA_14 and MAA_22) in the winter samples. correspond to any group, even though it contained eight different MAAs. Shinorine was present in all species of Groups 2 and 3, except in $V$. lanosa which was also the only 
356 found in some species from Group 2, and in all species from Group 3 (with the

357 exception of $V$. lanosa and B. scorpioides). Finally, there were some MAAs which were

358 only found in Group 3, notably usujirene and palythene which were present in six of the

359 nine species of the Group 3 in winter. The high diversity in MAAs did not seem to be

360 related to phylogeny (Fig. 7B and Appendix 3B), anatomy and morphology, the height

361 on the shore nor the sampling site (Appendix 1). Hence, species which are close

362 phylogenetically (i.e. G. vermiculophylla and G. gracilis, or Callithamnion tetricum and

363 C. tetragonum in our study), morphologically (M. stellatus and C. crispus), or the only

364 two species harvested from a muddy habitat (i.e. B. scorpioides and G. vermiculophylla)

365 did not have the same MAAs profile (see Appendix 1 and Fig. 5). No link was also

366 found between the MAAs and the fact that a species was introduced or indigenous to

367 Brittany (data not shown).

\section{Discussion}

As intertidal macroalgae are organisms directly exposed to solar radiation, they have developed some protective mechanisms in order to survive, such as the synthesis

372 of photo-protective compounds. In this sense, the objective of this study was to collect many different red algal species from a temperate shore in order to have a first overview

374 of the specific distribution of these compounds, and more particularly of mycosporine-

375 like amino acids for which data are not actually available for some species.

Firstly, a high inter-specific variability has been demonstrated in terms of pigment composition and concentration (Figs 1-3). Some species had a high content of chlorophyll- $a$ (P. plumosa or Callithamnion sp.) while others had more carotenoids 
380 (P. dioica, B. scorpioides, V. lanosa), or others had low concentrations of both pigments

381 (C. crispus or G. pistillata). Three groups were observed from the carotenoids

382 composition, as suggested by Schubert et al. (2006): species rich in lutein, species rich

383 in zeaxanthin, and those with violaxanthin or antheraxanthin (Fig. 2). Lutein was the

384 major carotenoid, as already illustrated (Esteban et al., 2009; Marquardt and Hanelt, 385 2004).

Furthermore, the quantity of photosynthetic pigment (i.e. chlorophyll- $a$ and phycobiliproteins) decreased in the summer samples (Figs. 1,3) due to an increase in irradiance. Indeed, the increase in light energy availability leads species to reduce their pigment complement to harvest the same quantity of light (Ak and Yücesan, 2012; Ramus et al., 1976). Another explanation would be linked to the nitrogenous nature of chlorophyll- $a$ and phycobiliproteins (Huovinen et al., 2006; Lüning, 1990; Parjikolaie et al., 2013). They are used for nitrogen storage in winter and as a nitrogen source when

394 limitations occur in summer (Barufi et al., 2011; Lapointe and Duke, 1984; Surget et al., 2017). Stack et al. (2017) demonstrated that the protein content of Porphyra dioica doubled in winter months, perhaps because of phycobiliproteins acting as a nitrogen storage. In general, the impact of $\mathrm{N}$ concentration on pigments has already been widely demonstrated in many species such as in Palmaria palmata (Corey et al., 2013; Parjikolaei et al., 2013). of 40 red macroalgae. The extraction method in $70 \%$ ethanol, coupled with the extract analysis by HPLC, provided reliable data, and had the advantage of being non-toxic, 
404 unlike using methanol which is commonly used in the literature (e.g. Briani et al., 2018;

405 Gröniger et al., 2000; Guihéneuf et al., 2018; Pandey et al., 2017; Yuan et al., 2009).

406 The use of a less-toxic solvent such as ethanol allowed for the valorization of extracted

407 MAAs as they have a significant potential for biotechnology applications in for example

408 human health and cosmetics (Chrapusta et al., 2017; Lawrence et al., 2018; Pangestuti

409 et al., 2018). For example, Helioguard 365 (Mibelle group, Switzerland) is a

410 commercial formulation used to protect the skin or hair from UV radiation and based on

411 the MAAs shinorine and porphyra-334 extracted from the red macroalga Porphyra

412 umbilicalis (La Barre et al., 2014; Schmid et al., 2006).

414 the 40 studied species, including some species for which the MAA composition had not

415 been reported before, e.g. Plumaria plumosa, Bornetia secundiflora, Dilsea carnosa,

416 Gastroclonium ovatum, Hypoglossum hypoglossoides, Champia parvula and

417 Chylocladia verticillata. It was already demonstrated that some species of the

418 Rhodophyta have the capacity to accumulate a high degree of diversity and

419 concentration of MAAs (e.g. Rastogi et al., 2010; Sinha et al., 2007), but this present

420 study is the first to report on MAA profiles from as many species of red alga from a

421 temperate region, here from Brittany. Based on their absorption maxima and retention

422 time, 23 potential MAAs were identified by HPLC analyses in the 40 red seaweeds

423 harvested along the Brittany coasts. Shinorine and palythine were found to be the most

424 common MAAs in this study (Fig. 5), which is in agreement with Karentz (2001). The

425 composition in MAAs of each species coincided with the literature, even for poorly

426 studied species such as Asparagopsis armata (Figueroa et al., 2008). For example, in

427 accordance with the bibliography, shinorine and porphyra-334 are found in $P$. dioica 
428 (Guihéneuf et al., 2018); shinorine, palythine and porphyra-334 in C. nodulosum; or 429 species contained no MAA such as Phycodrys rubens and F. lumbricalis (Karsten et al., 430 1998b). three groups of species (Fig. 7A): i.e. species without MAA (e.g. Plumaria plumosa, H. plumosa, M. alata, Polyides rotunda or F. lumbricalis), species with a few MAAs (e.g. Porphyra dioica, Gracilaria gracilis, C. tetricum), and some with more than six MAAs (e.g. Palmaria palmata, B. scorpioides, Gracilaria vermiculophylla, V. lanosa). These observations suggested a huge diversity of mycosporine-like amino acids among different members of Rhodophyta, with no apparent link with phylogeny, or morphology, position on the shore or sampling site. Similarly to our study, the distribution of various MAAs in other publications is not related to a phylogenetic pattern (Karentz et al., 1991; McClintock and Karentz, 1997), but more to an acclimatization to environmental variations (Briani et al., 2018). were observed in the 40 species knowing that approximately 20 MAAs have been

444 reported so far in red algae, suggesting that there may be in this study some MAAs that 445 have never been yet identified. B. scorpioides was the species that stood out the most 446 because it had four, unique, as yet un-identified MAAs (i.e. MAA_4, MAA_13, 447 MAA_18 and MAA_23). This species also did not fit into any of the three groups based 448 on the diversity index (Fig. 7A). Only six MAAs were identified by LC-MS in the 449 studied species (i.e. shinorine, palythine, porphyra-334, asterina-330, usurijene, 450 palythene). In addition, we propose that MAA_11 corresponded to palythinol by 451 comparing the results with the literature: indeed, palythinol is a MAA often observed in 
452 many red macroalgae in the literature (Sinha et al., 2007) and MAAs_11 is the fifth

453 most common MAA in the red algae studied here. MAA_11 is present for example in

454 P. palmata, which should contain palythinol according to the litterature (Gröniger et al., 455 2000; Karsten and Wiencke, 1999; Yuan et al., 2009). It is difficult to identify MAAs

456 based only on the absorbance spectra and retention times of known MAAs in the

457 bibliography, especially since some MAAs are present in very small quantities which

458 makes it impossible to detect them in LC-MS. The lack of commercial standards makes

459 this study particularly complex, in addition to making impossible the quantification of

460 the different MAAs. In addition, some peaks have similar absorption maxima and

461 retention times. For example, usujirene and palythene only differ by their cis- or trans-

462 conformation and less than one minute separated them (Carreto and Carignan, 2011). In

463 order to identify other MAAs, more biomass for the extractions (if the available

464 biomass allowed it), or the development of a purification protocol to concentrate each

465 MAA would therefore be necessary.

Moreover, there was no large seasonal difference in terms of the composition

467 and concentration of MAAs (Fig. 5). This is an unexpected result as the role of photo-

468 protection by MAAs has been widely demonstrated (e.g. Conde et al., 2000; Singh et

469 al., 2008). We expected that the concentration of total MAAs would increase in relation

470 to the intensity of radiation in the marine ecosystem (Karsten et al., 1998a; Torres et al.,

471 2016). However, it is possible that a possible increase in MAAs content occurred

472 between the two sampling periods, February and July, indicating that two sampling

473 periods are not enough to study seasonal variation in MAAs content. This is suggested

474 by Guihéneuf et al. (2018), who found that the concentration of MAAs increased

475 between February and May in P. palmata and C. crispus collected on Irish shores and 
476 not during summer as expected. Another explanation is that, as MAAs are nitrogenous

477 compounds, they are used in summer as a source of nitrogen (Karentz, 2001). In this

478 sense, a number of studies have already demonstrated the positive effect of nitrogen on

479 concentrations of MAAs (Figueroa et al., 2014; Korbee et al., 2005; Peinado et al., 480 2004).

Thus, the variability observed in pigments and MAAs composition suggests that 482 all species do not seem to have the same protective capabilities against solar radiation.

483 In an attempt to obtain a first explanation of this diversity, we tried to relate this

484 composition to phylogeny, or morphology, position on the shore or sampling site, which was not successful. To date, few studies have examined the link between pigment composition and phylogeny, and no clear relationship has been found (Vandervelde, 1973; Wang et al., 2018). The MAAs composition would also not be related to a phylogenetic pattern (Karentz et al., 1991; McClintock and Karentz, 1997). Thus there is currently no explanation for the composition (presence/absence) in MAAs between the different species that seems to be random. However, it has been experimentally 491 demonstrated that an increase in UV radiation could have an impact on the levels of 492 MAAs, for example in Palmaria palmata or Chondrus crispus (Hoyer et al., 2002; 493 Kräbs et al., 2004); or that the MAAs concentration depended on the season (Guihéneuf 494 et al., 2018), nutrient concentrations and pH (Briani et al., 2018), latitude (Karsten et al. 495 1998b) or depth (Franklin et al., 1999; Karsten and Wiencke, 1999). For example, the 496 total MAA concentration in P. palmata and Devalerea ramentaceae collected at 497 different depths decrease with sampling depth, although the composition remains the 498 same (Hoyer et al., 2001; Karsten et al., 1999). 
In our study, four species stand out due to their diversified compositions of

501 MAAs: B. scorpioides, G. vermiculophylla, V. lanosa and P. dioica, which are the

502 sampled species the most exposed to solar radiation due to their relatively high position

503 on the shore. Indeed, B. scorpioides lives at the top of muddy estuaries (Sanchez de

504 Pedro et al., 2014); G. vermiculophylla lives at the surface of the intertidal muddy

505 estuaries (Roleda et al., 2012; Surget et al., 2017); P. dioica is located on the upper

506 intertidal, and $V$. lanosa is an obligate epiphyte on the brown macroalga Ascophyllum

507 nodosum (Garbary et al., 2014) which has a wide range of coverage on intertidal

508 rockyshores at mid-tide level. These four red algal species were characterized by the

509 presence of several MAAs and a high concentration of carotenoids, in particular

510 zeaxanthin, a pigment synthetized under higher light conditions (Rmiki et al., 1996;

511 Schubert and Garcia-Mendoza, 2008). Thus, they stood out from the others on the

512 Principal Component Analysis of pigments (Fig. 4). Another species, G. gracilis, also

513 stood out the PCA since it contained antheraxanthin, in accordance with Rmiki et al.

514 (1996) and Schubert et al. (2006). Conversely, P. plumosa, with no observed MAA, was

515 the single species with the highest concentrations of chlorophyll $a$ and phycoerythrin.

516 This alga lives in shaded areas (Yakovleva et al., 1998), which may explain its necessity

517 to have high concentrations of pigments which absorb light energy, rather than act as

518 photoprotectants.

\section{5. Conclusions}

521 This study highlights the occurrence of numerous MAAs in red macroalgae from

522 Brittany, with variations in the number and level of MAAs per species. Thus, this

523 research contributes to reinforce the few existing databases on the MAAs composition 
524 of red algae as described by Gröniger et al. (2000) and Sinha et al. (2007), knowing that

525 the identification of these molecules is difficult due to the lack of commercial standards.

526 Here we attempted to identify the factors controlling this MAAs diversity: MAAs

527 composition was no related to a phylogenetic pattern; however, the algal species most

528 exposed to light radiation were those with a high level and diversity of photoprotective

529 compounds which could protect their photosynthetic mechanisms against UV-radiation.

530 Nevertheless, it remains complex to provide conclusions about the actual impact of the

531 different biotic and abiotic factors on the synthesis of each MAA. Although MAAs

532 seem to be photo-protective, they may play other and as yet unknown roles in

533 macroalgal metabolism. Subsequently, it is necessary to select few species and carry out

534 macroalgal cultures under controlled conditions in order to understand factors

535 responsible for the production of each MAAs. Thus, the impact of temperature, UV

536 radiation, nutrients or $\mathrm{pH}$ could be tested one by one or in combination, allowing to

537 highlight a change in the ratio of MAAs for example. This would result in a better

538 understanding of the synthesis and function of these compounds.

539

540 Acknowledgements

541 We thank the European Institute for Marine Studies (IUEM), the University of

542 Western Brittany (UBO, Brest) and the region Bretagne for funding Fanny Lalegerie's

$543 \mathrm{PhD}$, and the region Bretagne for the post-doctoral fellowship of Sirine Lajili through

544 the SAD 2016 - MABIOPA (9648) project. Authors thanks T. Burel for the

545 identification of some studied species.

546

547 Authors' contributions 
548 F.L. performed the analysis of the samples collected in winter, drafted the manuscript

549 and conducted the statistical analyses. S.L. performed the analysis of the samples

550 collected in summer and contributed to the writing of the manuscript. G.B. and L.T.

551 performed the LC-MS analyses. V.S-P designed the diversity index, helped in carrying

552 out the phylogenetic analyses and contributed to the interpretation of the results. S.C.

553 designed and supervised the project. All authors reviewed and approved the final

554 manuscript.

\section{References}

557 Ak, I., Yücesan, M., 2012. Effect of light intensity on the pigment composition of 558 Gracilaria verrucosa (Rhodophyta). Fresenius Environmental Bulletin 21, 2126559 2131. DOI: 10.1016/S1011-1344(99)00086-X

560 Ar Gall, E., Le Duff, M., 2014. Development of a quality index to evaluate the structure of macroalgal communities. Estuarine, Coastal and Shelf Science 139, 99-109. DOI: 10.1016/j.ecss.2013.12.028

Bandaranayake, W.M., 1998. Mycosporines: are they nature's sunscreens? Natural Product Reports 15, 159-172. DOI: 10.1039/A815159Y

Barufi, J.B., Korbee, N., Oliveira, M.C., Figueroa, F.L., 2011. Effects of N supply on the accumulation of photosynthetic pigments and photoprotectors in Gracilaria tenuistipitata (Rhodophyta) cultured under UV radiation. Journal of Applied Phycology 23, 457-466. DOI: 10.1007/s10811-010-9603-x

Bedoux, G., Hardouin, K., Marty, C., Taupin, L., Vandanjon, L., Bourgougnon, N., 2014. Chemical characterization and photoprotective activity measurement of extracts from the red macroalga Solieria chordalis. Botanica Marina 57, 291-330. DOI: $10.1515 /$ bot-2013-0118 $\square$

Beer, S., Eshel, A., 1985. Determining phycoerythrin and phycocyanin concentrations in aqueous crude extracts of red algae. Marine and Freshwater Research 36, 785792. DOI: 10.1071/MF9850785

Bhatia, S., Sharma, K., Sharma, A., Purohit, A.P., 2011. Mycosporine and mycosporine-like amino acids: A paramount tool against ultra violet irradiation. Pharmacognosy Reviews 5, 138-146. DOI: 10.4103/0973-7847.91107

Bischof, K., Gómez, I., Molis, M., Hanelt, D., Karsten, U., Lüder, U., Roleda, M.Y., Zacher, K., Wiencke, C., (2006). Ultraviolet radiation shapes seaweed communities. Reviews in Environmental Science and Bio/Technology 5, 141-166. DOI: 10.1007/s11157-006-0002-3

Briani, B., Sissini, M.N., Lucena, L.A., Batista, M.B., Costa, I.O., Nunes, J.M.C., Schmitz, C., Ramlov, F., Maraschin, M., Korbee, N., Rörig, L., Horta, P.A., Figueroa, F.L., Barufi, J.B., 2018. The influence of environmental features in the 
600

601

602

603

604

605

606

607

608

609

610

611

612

613

614

615

616

617

618

619

620

621

622

623

624

625

626

627

628

629

630

631

632

633

content of mycosporine $\square$ like amino acids in red marine algae along the Brazilian coast. Journal of Phycology 54, 380-390. DOI: 10.1111/jpy.12640

Carreto, J.I., Carignan, M.O., 2011. Mycosporine- Like Amino Acids: Relevant Secondary Metabolites. Chemical and Ecological Aspects. Marine Drugs 9, 387446. DOI: $10.3390 / \mathrm{md} 9030387$

Carreto, J.I., Carignan, M.O., Montoya, N.G., Cozzolino, E., Akselman, R., 2018. Mycosporine-like amino acids and xanthophyll-cycle pigments favour a massive spring bloom development of the dinoflagellate Prorocentrum minimum in Grande Bay (Argentina), an ozone hole affected area. Journal of Marine Systems 178, 15-28. DOI: 10.1016/j.jmarsys.2017.10.004

Chrapusta, E., Kaminski, A., Duchnik, K., Bober, B., Adamski, M., Bialczyk, J., 2017. Mycosporine-Like Amino Acids: Potential Health and Beauty Ingredients. Marine Drugs 15, 326. DOI: 10.3390/md15100326

Conde, F.R., Churio, M.S., Previtali, C.M., 2000. The photoprotector mechanism of mycosporine-like amino acids. Excited-state properties and photostability of porphyra-334 in aqueous solution. Journal of Photochemistry and Photobiology B 56, 139-144. DOI: 1011-1344(00)00066-X

Corey, P., Kim, J.K., Duston, J., Garbary, D.J., Prithiviraj, B., 2013. Bioremediation potential of Palmaria palmata and Chondrus crispus (Basin Head): effect of nitrate and ammonium ratio as nitrogen source on nutrient removal. Journal of Applied Phycology 25, 1349-1358. DOI: 10.1007/s10811-013-9977-7

Davison, I.R., Pearson, G.A., 1996. Stress tolerance in intertidal seaweeds. Journal of Phycology 32, 197-211. DOI: 10.1111/j.0022-3646.1996.00197.x

De la Coba, F., Aguilera, A.J., Figueroa, F.L., De Gálvez, M.V., Herrera, E., 2009. Antioxidant activity of mycosporine-like amino acids isolated from three red macroalgae and one marine lichen. Journal of Applied Phycology 21, 161-169. DOI: 10.1007/s10811-008-9345-1

Dumay, J., Morancais, M., Munier, M., Le Guillard, C., Fleurence, J., 2014. Phycoerythrins: valuable proteinic pigments in red seaweeds. Advance in Botanical Research 71, 321-343.

Dytham C., 2011. Choosing and using statistics: a biologist's guide, 3rd edition. Oxford, UK, Wiley-Blackwell. p 298.

Esteban, R., Martinez, B., Fernandez-Marin, B., Becerril, J.M., Garcia-Plazaola, J.I., 2009. Carotenoid composition in Rhodophyta: insights into xanthophyll regulation in Corallina elongata. European Journal of Phycology 44, 221-230. DOI: 10.1080/09670260802439109

Figueroa, F.L., Barufi, J.B., Malta, E., Conde-Alvarez, R., Nitschke, U., Arenas, F., Mata, M., Connan, S., Abreu, M.H., Marquardt, R., Vaz-Pinto, F., Konotchick, K., Celis-Pla, P.S.M., Hermoso, M., Ordonez, G., Ruiz, E., Flores, P., De los Rios, J., Kirke, D., Chow, F., Nassar, C.A.G., Robledo, D., Perez-Ruzafa, A., BanaresEspana, E., Altamirano, M., Jimenez, C., Korbee, N., Bischof, K., Stengel, D.B., 2014. Short-term effects of increasing $\mathrm{CO}_{2}$, nitrate and temperature on three Mediterranean macroalgae: biochemical composition. Aquatic Biology 22, 177-193. DOI: $10.3354 / \mathrm{ab} 00610$

Figueroa, F.L., Bueno, A., Korbee, N., Santos, R., Mata, L., Schuenhoff, A., 2008. Accumulation of Mycosporine-like Amino Acids in Asparagopsis armata Grown in Tanks with Fishpond Effluents of Gilthead Sea Bream, Sparus aurata. Journal of the World Aquaculture Society 39, 692-699. DOI: 10.1111/j.1749-7345.2008.00199.x 
634 Franklin, LA., Yakovleva, I., Karsten, U., Lüning, K., 1999. Synthesis of mycosporine-

635

636

637

638

639

640

641

642

643

644

645

646

647

648

649

650

651

652

653

654

655

656

657

658

659

660

661

662

663

664

665

666

667

668

669

670

671

672

673

674

675

676

677

678

679

680

681 like amino acids in Chondrus crispus (Florideophyceae) and the consequences for sensitivity to ultraviolet B radiation. Journal of Phycology 35, 682-693. DOI: 10.1046/j.1529-8817.1999.3540682.x

Gantt, E., 1990. Pigmentation and photoacclimation, in: Cole, K.M., Sheath, R.G. (Eds.), Biology of the Red Algae, Cambridge University Press, New York, pp. 203220.

Garbary, D.J., Miller, A.G., Scrosati, R.A., 2014. Ascophyllum nodosum and its symbionts: XI. The epiphyte Vertebrata lanosa performs better photosynthetically when attached to Ascophyllum than when alone. Algae 29, 321-331. DOI: 10.4490/algae.2014.29.4.321

Goss, R., Jakob, T., 2010. Regulation and function of xanthophyll cycle-dependent photoprotection in algae. Photosynthesis Research 106, 103-122. DOI: 10.1007/s11120-010-9536-X

Gröniger, A., Sinha, R.P., Klisch, M., Häder, D.P., 2000. Photoprotective compounds in cyanobacteria, phytoplankton and macroalgae - a database. Journal of Photochemistry and Photobiology B 58, 115-122. DOI: 10.1016/S10111344(00)00112-3

Guihéneuf, F., Gietl, A., Stengel, D.B., 2018. Temporal and spatial variability of mycosporine-like amino acids and pigments in three edible red seaweeds from western Ireland. Journal of Applied Phycology 30, 2573-2586. DOI: 10.1007/s10811-018-1436-Z

Hall, T.A., 1999. BioEdit: a user-friendly biological sequence alignment editor an analysis program for Windows 96/98/NT. Nucleic Acids Symposium Series 41, 9598.

Hartmann, A., Holzinger, A., Ganzera, M., Karsten, U., 2016. Prasiolin, a new UVsunscreen compound in the terrestrial green macroalga Prasiola calophylla (Carmichael ex Greville) Kützing (Trebouxiophyceae, Chlorophyta). Planta 243, 161-169. DOI: 10.1007/s00425-015-2396-z

Hashimoto, H., Uragami, C., Cogdell, R.J., 2016. Carotenoids and photosynthesis, in: Stange, C. (Ed.), Carotenoids in Nature: Biosynthesis, regulation and function, Springer, Switzerland, pp. 111-139.

Holdt, S.L., Kraan, S., 2011. Bioactive compounds in seaweed: functional food applications and legislation. Journal of Applied Phycology 23, 543-597. DOI: 10.1007/s10811-010-9632-5

Hoyer, K., Karsten, U., Sawall, T., Wiencke, C., 2001. Photoprotective substances in Antarctic macroalgae and their variation with respect to depth distribution, different tissues and developmental stages. Marine Ecology Progress Series 211, 117-129. DOI: $10.3354 / \mathrm{meps} 211117$

Hoyer, K., Karsten, U., Wiencke, C., 2002. Induction of sunscreen compounds in antarctic macroalgae by different radiation conditions. Marine Biology 141, 619627. DOI: 10.1007/s00227-002-0871-0

Huovinen, P., Gomez, I., Figueroa, F.L., Ulloa, N., Morales, V., Lovengreen, C., 2004. Ultraviolet- absorbing mycosporine-like amino acids in red macroalgae from Chile. Botanica Marina 47, 21-29. DOI: 10.1515/BOT.2004.003

Huovinen, P., Matos, J., Pinto, I.S., Figueroa, F.L., 2006. The role of ammonium in photoprotection against high irradiance in the red alga Grateloupia lanceola. Aquatic Botany 84, 308-316. DOI: 10.1016/j.aquabot.2005.12.002 
682

683

684

685

686

687

688

689

690

691

692

693

694

695

696

697

698

699

700

701

702

703

704

705

706

707

708

709

710

711

712

713

714

715

716

717

718

719

720

721

722

723

724

725

726

727

728

Karentz, D., 2001. Chemical Defenses of Marine Organisms Against Solar Radiation Exposure: UV-Absorbing Mycosporine-Like Amino Acids and Scytonemin, in: McClintock, J., Baker, B.J. (Eds.), Marine chemical ecology, CRC Press, Boca Raton, pp. 481-520.

Karentz, D., McEuen, F.S., Land, M.C., Dunlap, W.C., 1991. Survey of mycosporinelike amino acid compounds in Antarctic marine organisms: potential protection from ultraviolet exposure. Marine Biology 108, 157-166. DOI: 10.1007/BF01313484

Karsten, U., 2008. Defense strategies of algae and cyanobacteria against solar ultraviolet radiation, in: Amsler, C.D. (Ed.), Algal Chemical Ecology, Springer, Berlin, pp. 273-296.

Karsten, U., Bischof, K., Hanelt, D., Tüg, H., Wiencke, C., 1999. The effect of ultraviolet radiation on photosynthesis and ultraviolet-absorbing substances in the endemic Arctic macroalga Devaleraea ramentacea (Rhodophyta). Physiologia Plantarum 105, 58-66. DOI: 10.1034/j.1399-3054.1999.105110.x

Karsten, U., Franklin, L.A., Lüning, K., Wiencke, C., 1998a. Natural ultraviolet radiation and photosynthetically active radiation induce formation of mycosporinelike amino acids in the marine macroalga Chondrus crispus (Rhodophyta). Planta 205, 257-262. DOI: $10.1007 / \mathrm{s} 004250050319$

Karsten, U., Sawall, T., Hanelt, D., Bischof, K., Figueroa, F.L., Flores-Moya, A., Wiencke, C., 1998b. An inventory of UV-absorbing mycosporine-like amino acids in macroalgae from polar to warm-temperate regions. Botanica Marina 41, 443-453. DOI: $10.1515 /$ botm.1998.41.1-6.443

Karsten, U., Wiencke, C., 1999. Factors controlling the formation of UV-absorbing mycosporine-like amino acids in the marine red alga Palmaria palmata from Spitsbergen (Norway). Journal of Plant Physiology 155, 407-415. DOI: 10.1016/S0176-1617(99)80124-2

Korbee, N., Huovinen, P., Figueroa, F.L., Aguilera, J., Karsten, U., 2005. Availability of ammonium influences photosynthesis and the accumulation of mycosporine-like amino acids in two Porphyra species (Bangiales, Rhodophyta). Marine Biology 146, 645-654. DOI: 10.1007/s00227-004-1484-6

Kräbs, G., Watanabe, M., Wiencke, C., 2004. A monochromatic action spectrum for the photoinduction of the UV absorbing mycosporine-like amino acid in the red alga Chondrus crispus. Photochemistry and Photobiology 79, 515-519. DOI: 10.1562/2003-12-14-RA.1

Kumar, S., Stecher, G., Tamura, K., 2016. MEGA7: Molecular Evolutionary Genetics Analysis version 7.0 for bigger datasets. Molecular Biology and Evolution 33, 18701874. DOI: $10.1093 / \mathrm{molbev} / \mathrm{msw} 054$

La Barre, S., Roullier, C., Boustie, J., 2014. Mycosporine-like amino acids (MAAs) in biological photosystems, in: La Barre, S., Kornprobst, J.M. (Eds.), Outstanding Marine Molecules: Chemistry, Biology, Analysis, Wiley-Blackwell, Weinheim, pp. 333-360.

Lapointe, B. E., Duke, C. S., 1984. Biochemical strategies for growth of Gracilaria tikvahiae (Rhodophyta) in relation to light intensity and nitrogen availability. Journal of Phycology 20, 488-495. DOI: 10.1111/j.0022-3646.1984.00488.x

Latowski, D., Kuczyńska, P., Strzałka, K., 2011. Xanthophyll cycle - a mechanism protecting plants against oxidative stress. Redox Report 16, 78-90. DOI: 10.1179/174329211X13020951739938 
Lawrence, K.P., Gacesa, R., Long, P.F., Young, A.R., 2018. Molecular photoprotection of human keratinocytes in vitro by the naturally occurring mycosporine-like amino acid palythine. British Journal of Dermatology 178, 1353-1363. DOI: $10.1111 /$ bjd. 16125

Leach, C.M., 1965. Ultraviolet-absorbing substances associated with light-induced sporulation in fungi. Canadian Journal of Botany 43, 185-200. DOI: doi.org/10.1139/b65-024

Le Lann, K., Surget, G., Couteau, C., Coiffard, L., Cérantola, S., Gaillard, F., Larnicol, M., Zubia, M., Guérard, F., Poupart, N., Stiger-Pouvreau, V., 2016. Sunscreen, antioxidant, and bactericide capacities of phlorotannins from the brown macroalga Halidrys siliquosa. Journal of Applied Phycology 28, 3547-3599. DOI: 10.1007/s10811-016-0853-0

Lobban, C.S., Harrison, P.J., 1994. Seaweed ecology and physiology, Cambridge University Press, New York.

Lüning, K., 1990. Seaweeds: Their Environment, Biogeography and Ecophysiology, John Wiley and Sons, New York.

Marquardt, J., Hanelt, D., 2004. Carotenoid composition of Delesseria lancifolia and other marine red algae from polar and temperate habitats. European Journal of Phycology 39, 285-292. DOI: 10.1080/09670260410001712572

McClintock, J.B., Karentz, D., 1997. Mycosporine-like amino acids in 38 species of subtidal marine organisms from McMurdo Sound, Antarctica. Antarctic Science 9, 392-398. DOI: 10.1017/S0954102097000503

McKenzie, R.L., Aucamp, P.J., Bais, A.F., Björn, L.O., Ilyas, M., 2007. Changes in biologically active ultraviolet radiation reaching the Earth's surface. Photochemical and Photobiological Sciences 6, 218-231. DOI: 10.1039/b700017k

McKenzie, R.L., Aucamp, P.J., Bais, A.F., Björn, L.O., Ilyas, M., Madronich, S., 2011. Ozone depletion and climate change: impacts on UV radiation. Photochemical and Photobiological Sciences 10, 182-198. DOI: 10.1039/c0pp90034f

Mimuro, M., Akimoto, S., 2003. Carotenoids of Light Harvesting Systems: Energy Transfer Processes from Fucoxanthin and Peridinin to Chlorophyll, in: Larkum, A.W.D., Douglas, S.E., Raven, J.A. (Eds.), Photosynthesis in Algae, Springer, Netherlands, pp. 335-349.

Oren, A., Gunde-Cimerman, N., 2007. Mycosporines and mycosporine-like amino acids: UV protectants or multipurpose secondary metabolites? FEMS Microbiology Letters 269, 1-10. DOI: 10.1111/j.1574-6968.2007.00650.x

Pandey, A., Pandey, S., Rajneesh, Pathak, J., Ahmed, H., Singh, V., Singh, S.P., Sinha, R.P., 2017. Mycosporine-like amino acids (MAAs) profile of two marine red macroalgae, Gelidium sp. and Ceramium sp. International Journal of Applied Sciences and Biotechnology 5, 12-21. DOI: 10.3126/ijasbt.v5i1.16568

Pangestuti, R., Siahaan, E., Kim, S.K., 2018. Photoprotective Substances Derived from Marine Algae. Marine Drugs 16, 399. DOI: 10.3390/md16110399

Parjikolaei, B.R., Kloster, L., Bruhn, A., Rasmussen, M.B., Fretté, X.C., Christensen, L.V., 2013. Effect of light quality and nitrogen availability on the biomass production and pigment content of Palmaria palmata (Rhodophyta). Chemical Engineering Transactions 32, 967-972. DOI: 10.3303/CET1332162

Peinado, N.K., Abdala, Díaz R.T., Figueroa, F.L., Helbling, E.W., 2004. Ammonium and UV radiation stimulate the accumulation of mycosporine-like amino acids in 
800

801

802

803

804

805

806

807

808

809

810

811

812

813

814

815

816

817

818

819

820

821

822

Porphyra columbina (Rhodophyta) from Patagonia, Argentina. Journal of Phycology 40, 248-259. DOI: 10.1046/j.1529-8817.2004.03013.x

Pelillo, M., Cuvelier, M., Biguzzi, B., Toschi, T.G., Berset, C., Lercker, G., 2004. Calculation of the molar absorptivity of polyphenols by using liquid chromatography with diode array detection: the case of carnosic acid. Journal of Chromatography A 1023, 225-229. DOI: 10.1016/S0021-9673(03)01206-8

Ramus, J., Beale, S.I., Mauzerall, D., Howard, K.L., 1976. Changes in photosynthetic pigment concentration in seaweeds as a function of water depth. Marine Biology 37, 223-229. DOI: 10.1007/BF00387607

Rastogi, R.P., Sinha, R.P., Singh, S.P., Häder, D.P., 2010. Photoprotective compounds from marine organisms. Journal of Industrial Microbiology and Biotechnology 37, 537-558. DOI: 10.1007/s10295-010-0718-5

R Development Core team, 2008. R: A language and environment for statistical computing. R Foundation for Statistical Computing, Vienna, Austria. ISBN 3900051-07-0, http://www.R-project.org

Rmiki, N.E., Brunet, C., Cabioc'h, J., Lemoine, Y., 1996. Xanthophyll-cycle and photosynthetic adaptation to environment in macro-and microalgae. Hydrobiologia 327, 407-413. DOI: 10.1007/BF00047839

Roleda, M.Y., Nyberg, C.D., Wulff, A., 2012. UVR defense mechanisms in eurytopic and invasive Gracilaria vermiculophylla (Gracilariales, Rhodophyta). Physiologia Plantarum 146, 205-216. DOI: 10.1111/j.1399-3054.2012.01615.x

Roleda, M.Y., Van de Poll, W.H., Hanelt, D., Wiencke, C., 2004. PAR and UVBR effects on photosynthesis, viability, growth and DNA in different life stages of two coexisting Gigartinales: implications for recruitment and zonation pattern. Marine Ecology Progress Series 281, 37-50. DOI: 10.3354/meps281037

Rosic, N.N., Braun, C., Kvaskoff, D., 2015. Extraction and Analysis of MycosporineLike Amino Acids in Marine Algae, in: Stengel, D.B., Connan, S. (Eds.), Natural Products From Marine Algae: Methods and Protocols, Springer, New-York, pp. 119129.

Sagert, S., Forster, R.M., Feuerpfeil, P., Schubert, H., 1997. Daily course of photosynthesis and photoinhibition in Chondrus crispus (Rhodophyta) from different shore levels. European Journal of Phycology 32, 363-371. DOI: 10.1080/09670269710001737299

Sánchez de Pedro, R., Niell, F.X., Carmona, R., 2014. Understanding the intertidal zonation of two estuarine red macroalgae from ex situ photoacclimative responses. European Journal of Phycology 49, 538-549. DOI: 10.1080/09670262.2014.978394

Schmid, D., Schürch, C., Zülli, F., 2006. Mycosporine-like amino acids from red algae protect against premature skin-aging. Euro Cosmetics 9, 1-4.

Schmid, M., Stengel, D.B., 2015. Intra-thallus differenciation of fatty acid and pigment profiles in some temperate Fucales and Laminariales. Journal of Phycology 51, 2536. DOI: 10.1111/jpy.12268

Schubert, N., Garcia-Mendoza, E., 2008. Photoinhibition in red algal species with different carotenoid profiles. Journal of Phycology 44, 1437-1446. DOI: 10.1111/j.1529-8817.2008.00590.x

Schubert, N., Garcia-Mendoza, E., Pacheco-Ruiz, I., 2006. Carotenoid composition of marine red algae. Journal of Phycology 42, 1208-1216. DOI: 10.1111/j.15298817.2006.00274.x 
823

824

825

826

827

828

829

830

831

832

833

834

835

836

837

838

839

840

841

842

843

844

845

846

847

848

849

850

851

852

853

854

855

856

857

858

859

860

861

862

863

864

865

866

867

868

Singh, S.P., Kumari, S., Rastogi, R.P. Singh, K.L, Sinha, R.P, 2008. Mycosporine-like amino acids (MAAs): Chemical structure, biosynthesis and significance as UVabsorbing/screening compounds. Indian Journal of Experimental Biology 46, 7-17.

Sinha, R.P., Singh, S.P., Häder, D.P., 2007. Database on mycosporines and mycosporine-like amino acids (MAAs) in fungi, cyanobacteria, macroalgae, phytoplankton and animals. Journal of Photochemistry and Photobiology B 89, 2935. DOI: 10.1016/j.jphotobiol.2007.07.006

Stack, J., Tobin, P.R., Gietl, A., Harnedy, P.A., Stengel, D.B., FitzGerald, R.J., 2017. Seasonal variation in nitrogenous components and bioactivity of protein hydrolysates from Porphyra dioica. Journal of Applied Phycology 29, 2439-2450. DOI: 10.1007/s10811-017-1063-0

Steneck, R.S., Dethier, M.N., 1994. A functional group approach to the structure of algal-dominated communities. Oikos 69, 476-498.

Stengel, D.B., Connan, S., Popper, Z.A., 2011. Algal chemodiversity and bioactivity: Sources of natural variability and implications for commercial application. Biotechnology Advances 29, 483-501. DOI: 10.1016/j.biotechadv.2011.05.016 Stiger-Pouvreau, V., Guérard, F., 2018. Bio-Inspired Molecules Extracted from Marine Macroalgae: A New Generation of Active Ingredients for Cosmetics and Human Health, in: La Barre, S., Bates, S.S. (Eds.), Blue biotechnology: production and use of marine molecules, Wiley-VCH, Weinheim, pp. 709-746.

Sun, L., Wang, S., Gong, X., Zhao, M., Fu, X., Wang, L., 2009. Isolation, purification and characteristics of R-phycoerythrin from a marine macroalga Heterosiphonia japonica. Protein Expression and Purification 64, 146-154. DOI: 10.1016/j.pep.2008.09.013

Surget, G., Le Lann, K., Delebecq, G., Kervarec, N., Donval, A., Poullaouec, M.A., Bihannic, I., Poupart, N., Stiger-Pouvreau, V., 2017. Seasonal phenology and metabolomics of the introduced red macroalga Gracilaria vermiculophylla, monitored in the Bay of Brest (France). Journal of Applied Phycology 29, 26512666. DOI: $10.1007 / \mathrm{s} 10811-017-1060-3$

Thomas, P., Swaminathan, A., Lucas, R.M., 2012. Climate change and health with an emphasis on interactions with ultraviolet radiation: a review. Global Change Biology 18, 2392-2405. DOI: 10.1111/j.1365-2486.2012.02706.x

Torres, P.B., Chow, F., Ferreira, M.J.P., Dos Santos, D.Y.A.C., 2016. Mycosporine-like amino acids from Gracilariopsis tenuifrons (Gracilariales, Rhodophyta) and its variation under high light. Journal of Applied Phycology 28, 2035-2040. DOI: 10.1007/s10811-015-0708-0

Torres, P.B., Santos, J.P., Chow, F., Ferreira, M. J.P., Dos Santos, D.Y.A.C., 2018. Comparative analysis of in vitro antioxidant capacities of mycosporine-like amino acids (MAAs). Algal Research 34, 57-67. DOI: 10.1016/j.algal.2018.07.007

Van de Poll, W.H., Eggert, A., Buma, A.G.J., Breeman, A.M., 2001. Effects of UV-Binduced DNA damage and photoinhibition on growth of temperate of marine red macrophytes: habitat related differences in UV-B tolerance. Journal of Phycology 37, 30-37. DOI: 10.1046/j.1529-8817.2001.037001030.x

Vandervelde, H.H., 1973. The use of phycoerythrin absorption spectra in the classification of Red Algae. Acta Botanica Neerlandica 22, 92-99. DOI: 10.1111/j.1438-8677.1973.tb00817.x 
869 Wada, N., Sakamoto, T., Matsugo, S., 2015. Mycosporine-Like Amino Acids and Their

870 Derivatives as Natural Antioxidants. Antioxidants 4, 603-646. DOI:

$871 \quad$ 10.3390/antiox4030603

872

873

874

875

876

877

878

879

880

881

882

883

884

885

886

887

888

Wang, S., Zhang, L., Chi, S., Wang, G., Wang, X., Liu, T., Tang, X., 2018. Phylogenetic analyses of the genes involved in carotenoid biosynthesis in algae. Acta Oceanologica Sinica 37, 89-101. DOI: 10.1007/s13131-018-1178-4

Wilmouth, D.M., Salawitch, R.J., Canty, T.P., 2018. Stratospheric Ozone Depletion and Recovery, in: Török, B., Dransfield, T. (Eds.), Green Chemistry, Elsevier, Boston, pp. 177-209. DOI: 10.1016/B978-0-12-809270-5.00008-X

Woolley, J.M., Staniforth, M., Horbury, M.D., Richings, G.W., Wills, M., Stavros, V.G., 2018. Unravelling the photoprotection properties of Mycosporine Amino Acid motifs. Journal of Physical Chemistry Letters 9, 3043-3048. DOI: 10.1021/acs.jpclett.8b00921

Yakovleva, I.M., Dring, M., Titlyanov, E.A., 1998. Tolerance of North Sea algae to UV and visible radiation. Russian Journal of Plant Physiology 45, 45-54.

Young, A.J., Frank, H.A., 1996. Energy transfer reactions involving carotenoids: quenching of chlorophyll fluorescence. Journal of Photochemistry and Photobiology B 36, 3-15. DOI: 10.1016/S1011-1344(96)07397-6

Young, A., Phillip, D., Ruban, A.V., Horton, P., Frank, H., 1997. The xanthophyll cycle and carotenoid-mediated dissipation of excess excitation energy in photosynthesis.

889 Pure and Applied Chemistry 69, 2125-2130. DOI: 10.1351/pac199769102125

890 Yuan, Y.V., Westcott, N.D., Hu, C., Kitts, D.D., 2009. Mycosporine-like amino acid 891 composition of the edible red alga, Palmaria palmata (dulse) harvested from the 892 west and east coasts of Grand Manan Island, New Brunswick. Food Chemistry 112, 893 321-328. DOI: 10.1016/j.foodchem.2008.05.066 
Table 1. HPLC solvent gradient. (A) methanol:ammonium acetate buffer $0.5 \mathrm{M}$ (80:20), (B) acetonitrile:milliQ water (87.5:13.5), (C) ethylacetate $100 \%$.

\begin{tabular}{cccc}
\hline $\begin{array}{r}\text { Time } \\
(\text { min })\end{array}$ & $\% \mathrm{~A}$ & $\% \mathrm{~B}$ & $\% \mathrm{C}$ \\
\hline 0 & 90 & 10 & 0 \\
1 & 0 & 100 & 0 \\
11 & 0 & 78 & 22 \\
24 & 0 & 25 & 75 \\
26 & 0 & 25 & 75 \\
27 & 0 & 100 & 0 \\
28 & 90 & 10 & 0 \\
33 & 90 & 10 & 0 \\
\hline
\end{tabular}


Appendix 1. List of the 40 red macroalgal species collected in February and/or July 2017, with their associated GenBank accession numbers (for the genes $r b c \mathrm{~L}$ and cox 1), morpho-anatomical group (i.e. MAG; according to Steneck and Dethier, 1994), localisation on the shore, substrate and sampling site. The different MAGs are: (2) filamentous algae; (2.5) corticated or polysiphonous filaments algae; (3) foliose algae; (3.5) corticated foliose algae; (4) corticated algae and (6) articulated calcareous algae.

\begin{tabular}{lccccccc}
\cline { 5 - 6 } Species & \multicolumn{2}{c}{ Accession numbers } & & & & \\
\cline { 2 - 5 } Ahnfeltiopsis devoniensis & KU640212.1 & KF641876.1 & 4 & Lower intertidal & Rocky & Portsall \\
\hline \hline Asparagopsis armata & GQ337068.1 & KJ960343.1 & 2.5 & Lower intertidal & Rocky & Portsall \\
\hline Bonnemaisonia hamifera & FJ195604.1 & KJ960353.1 & 2.5 & Lower intertidal & Rocky & Portsall \\
\hline Bornetia secundiflora & & No data & 2.5 & Upper subtidal & Rocky & Portsall \\
\hline Bostrychia scorpioides & AY920825.1 & MF094019.1 & 2.5 & Upper intertidal & Muddy & Le Faou \\
\hline Calliblepharis jubata & KC121138.1 & KJ960410.1 & 4 & Lower intertidal & Rocky & Portsall \\
\hline Callithamnion tetragonum & AF439301.1 & MF447481.1 & 2 & Lower intertidal & Rocky & Portsall \\
\hline Callithamnion tetricum & AF439300.1 & KJ960434.1 & 2 & Lower intertidal & Rocky & Portsall \\
\hline Ceramium echionotum & AF439313.1 & KJ960509.1 & 2.5 & Lower intertidal & Rocky & Portsall \\
\hline Ceramium nodulosum & & No data & 2.5 & Lower intertidal & Rocky & Portsall \\
\hline
\end{tabular}




\begin{tabular}{|c|c|c|c|c|c|c|}
\hline Ceramium secundatum & KT250273.1 & KT250269.1 & 2.5 & Lower intertidal & Rocky & Portsall \\
\hline Champia parvula & EF613312.1 & HQ422864.1 & 2.5 & Lower intertidal & Rocky & Portsall \\
\hline Chondracanthus acicularis & KJ202090.1 & KJ202081.1 & 4 & Lower intertidal & Rocky & Portsall \\
\hline Chondrus crispus & KF026483.1 & GU645233.1 & 4 & Lower intertidal & Rocky & Portsall \\
\hline Chylocladia verticillata & \multicolumn{2}{|c|}{ No data } & 2.5 & Intertidal & Rocky & Portsall \\
\hline Corallina sp. & \multicolumn{2}{|c|}{ No data } & 6 & Lower intertidal & Rocky & Porspoder $^{\mathrm{a}} ; \mathrm{St}-\mathrm{Pabu}{ }^{\mathrm{b}}$ \\
\hline Dilsea carnosa & KT310705.1 & KY572820.1 & 3.5 & Upper subtidal & Rocky & Portsall \\
\hline Furcellaria lumbricalis & \multicolumn{2}{|c|}{ No data } & 4 & Intertidal & Rocky & Portsall \\
\hline Gastroclonium ovatum & KU726714.1 & KJ960700.1 & 2.5 & Lower intertidal & Rocky & Portsall \\
\hline Gelidium corneum & HM629821.1 & KJ960706.1 & 4 & Lower intertidal & Rocky & Porspoder \\
\hline Gigartina pistillata & AY294375.1 & KJ960717.1 & 4 & Lower intertidal & Rocky & Porspoder $^{\mathrm{a}}$; Portsall ${ }^{\mathrm{b}}$ \\
\hline Gracilaria gracilis & AY049400.1 & KF714853.1 & 4 & Lower intertidal & Rocky & Portsall \\
\hline Gracilaria vermiculophylla & JQ768774.1 & JQ794759.1 & 4 & Upper intertidal & Muddy & Le Faou \\
\hline Griffithsia corallinoides & \multicolumn{2}{|c|}{ No data } & 2.5 & Lower intertidal & Rocky & Portsall \\
\hline Heterosiphonia plumosa & AF083379.1 & KJ960780.1 & 2.5 & Upper subtidal & Rocky & Portsall $^{\mathrm{a}} ;$ St-Pabu ${ }^{\mathrm{b}}$ \\
\hline Hypoglossum hypoglossoides & AF257368.1 & KJ179930.1 & 3.5 & Lower intertidal & Rocky & Portsall \\
\hline
\end{tabular}




\begin{tabular}{|c|c|c|c|c|c|c|}
\hline Lomentaria articulata & KU726701.1 & KU707860.1 & 2.5 & Lower intertidal & Rocky & Portsall \\
\hline Mastocarpus stellatus & U02992.1 & KY572683.1 & 4 & Lower intertidal & Rocky & Portsall \\
\hline Membranoptera alata & JQ864359.1 & KJ960846.1 & 3.5 & Lower intertidal & Rocky & Portsall \\
\hline Metacallophyllis laciniata & \multicolumn{2}{|c|}{ No data } & 3.5 & Upper subtidal & Rocky & Portsall \\
\hline Osmundea hybrida & AF281878.1 & KX258831.1 & 4 & Lower intertidal & Rocky & Portsall \\
\hline Osmundea pinnatifida & JX828140.1 & KU566536.1 & 4 & Lower intertidal & Rocky & Porspoder $^{\mathrm{a}}$; Portsall ${ }^{\mathrm{b}}$ \\
\hline Palmaria palmata & LN999410.1 & KY572816.1 & 3.5 & Lower intertidal & Rocky & Porspoder $^{\mathrm{a}}$; Portsall ${ }^{\mathrm{b}}$ \\
\hline Phycodrys rubens & JX110932.1 & KY572841.1 & 3.5 & Upper subtidal & Rocky & Porspoder \\
\hline Plocamium cartilagineum & HQ224543.1 & JF271583.1 & 4 & Lower intertidal & Rocky & Portsall \\
\hline Plumaria plumosa & KU381993.1 & HQ412551.1 & 2.5 & Lower intertidal & Rocky & Portsall \\
\hline Polyides rotunda & \multicolumn{2}{|c|}{ No data } & 4 & Lower intertidal & Rocky & Portsall \\
\hline Porphyra dioica & JN703282.1 & JN847313.1 & 3 & Upper intertidal & Rocky & Portsall $^{\mathrm{a}} ;$ St-Pabu ${ }^{\mathrm{b}}$ \\
\hline Sphaerococcus coronopifolius & AY294376.1 & KJ961109.1 & 4 & Upper subtidal & Rocky & St-Pabu \\
\hline Vertebrata lanosa & MF120849.1 & KX344122.1 & 2.5 & Intertidal & Rocky & Portsall \\
\hline
\end{tabular}

${ }^{\mathrm{a}}$ Samples collected in winter; ${ }^{\mathrm{b}} \mathrm{S}$ amples collected in summer 


\section{Figure legends}

Figure 1. Chlorophyll $a$ concentrations (mg.g ${ }^{-1} \mathrm{DW}$ ) (mean \pm standard deviation, $\mathrm{n}=3$ ) of 40 red macroalgal species, collected from Brittany in February (winter) and July (summer) 2017. Blank spaces indicate that chlorophyll- $a$ level was below the limit of detection or quantification.

Figure 2. Carotenoid concentrations (mg.g $\left.{ }^{-1} \mathrm{DW}\right)($ mean, $\mathrm{n}=3)$ in 40 red macroalgal species, collected from Brittany in February (winter) and July (summer) 2017. Blank spaces indicate that carotenoids level was lower than the limit of detection or quantification.

Figure 3. Phycoerythrin concentrations $\left(\mathrm{mg} \cdot \mathrm{g}^{-1} \mathrm{DW}\right)$ (mean \pm standard deviation, $\mathrm{n}=3$ ) in 40 red macroalgal species, collected from Brittany in February (winter) and July (summer) 2017. Blank spaces indicate that phycoerythrin level was lower than the limit of quantification.

Figure 4. Principal Component Analysis (PCA) of pigment contents, for 21 species of red macroalgae collected in winter and summer (A: variables; B: samples). Ellipses were drawn around species that had a confidence level of $95 \%$ or more. Dimension 1 was principally characterised by chlorophyll $a$ level and dimension 2 by zeaxanthin presence and level (correlation coefficient $=0.93$ and 0.88 , respectively).

Figure 5. Mycosporine-like amino acids composition (mAU.min) (mean, n=3) in 40 red macroalgal species, collected from Brittany in February (winter) and July (summer) 2017. Blank spaces indicate that MAAs level was lower than the limit of detection or quantification. 
Figure 6. Chromatogram at $330 \mathrm{~nm}$ of MAAs extracted from the red macroalga Palmaria palmata collected in February 2017 (winter) from Porspoder (Brittany, France).

Figure 7. (A) Dendrogram based on the diversity indices of MAAs, obtained from hierarchical cluster analysis (single linkage method); (B) Neighbor-joining phylogenetic tree based on $r b c \mathrm{~L}$ and cox 1 genes sequences, for the 32 macroalgal species collected from Brittany during winter. The most relevant boot-strap values are shown next to the branches. Some species are not represented on the phylogenetic tree due to missing sequences on GenBank (see Appendix 1).

Appendix 2. List of the 23 different peaks analysed in 40 red macroalgae species, that may correspond to MAAs, with their absorption spectra, $\lambda_{\max }$ and their retention time (Rt).

Appendix 3. (A) Dendrogram based on the diversity indices of MAAs, obtained from hierarchical cluster analysis (single linkage method); (B) Neighbor-joining phylogenetic tree based on $r b c \mathrm{~L}$ and cox 1 genes sequences, for the 29 macroalgal species collected in summer. The most relevant boot-strap values are shown next to the branches. Some species are not represented on the phylogenetic tree due to missing sequences on GenBank (see Appendix 1). 


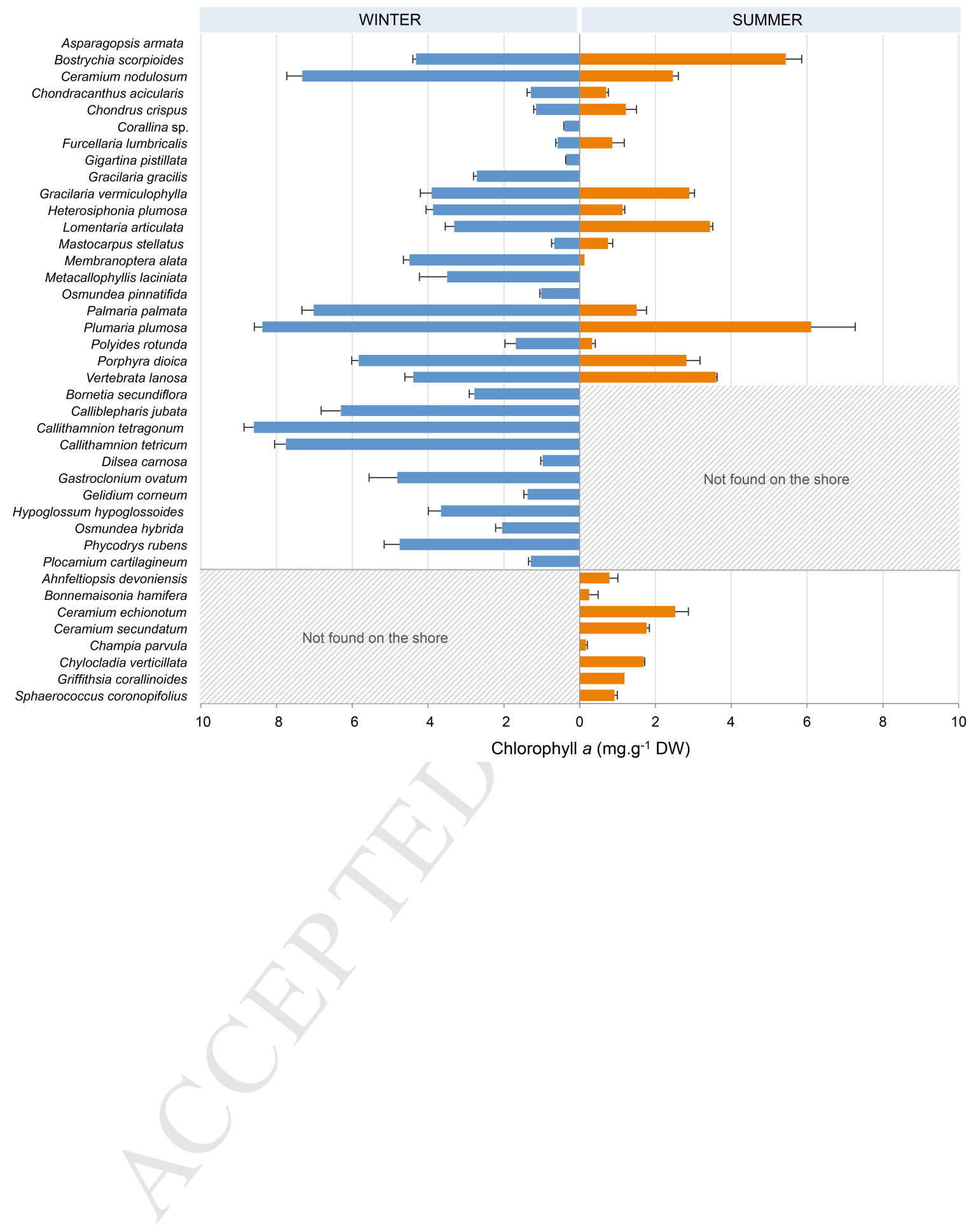




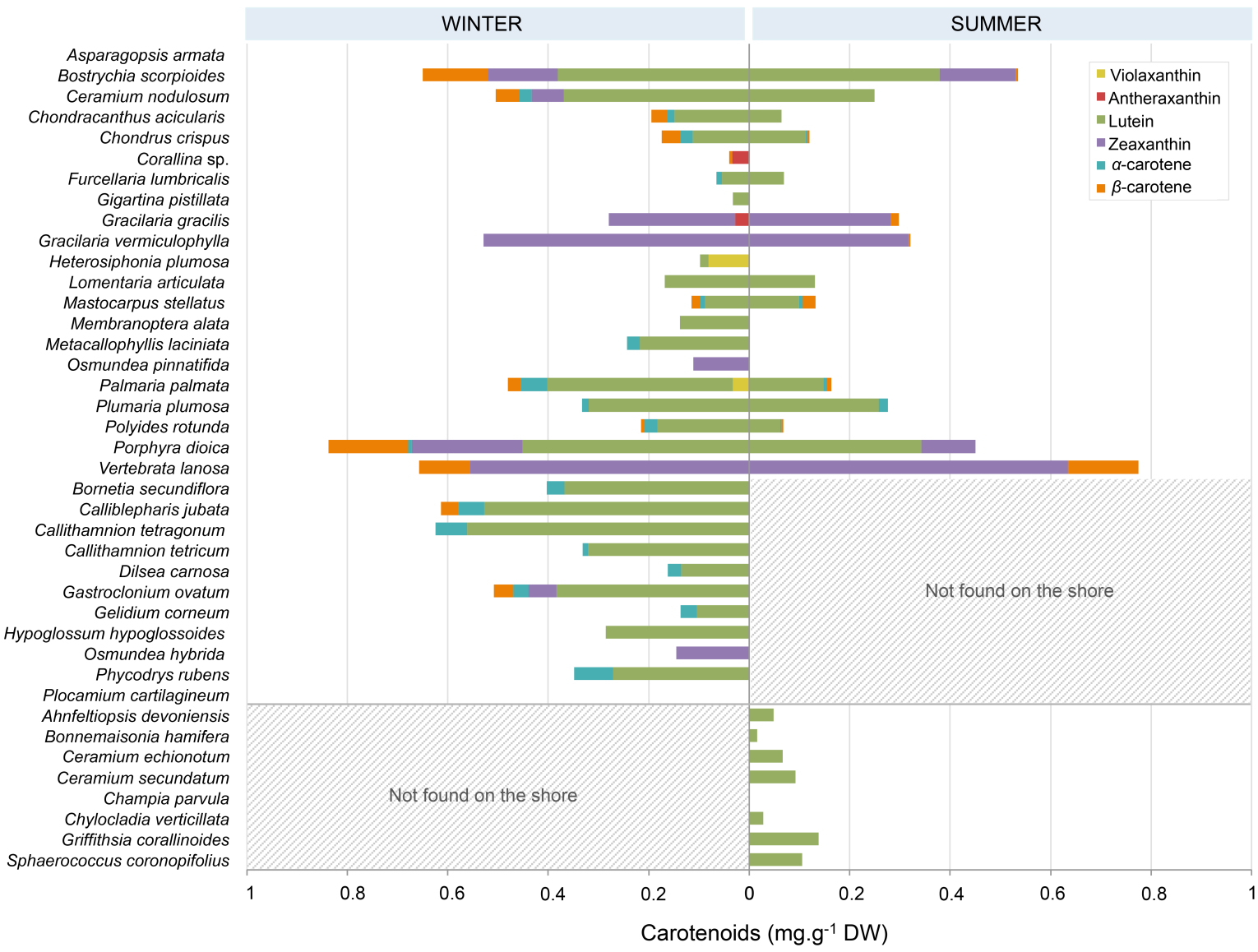




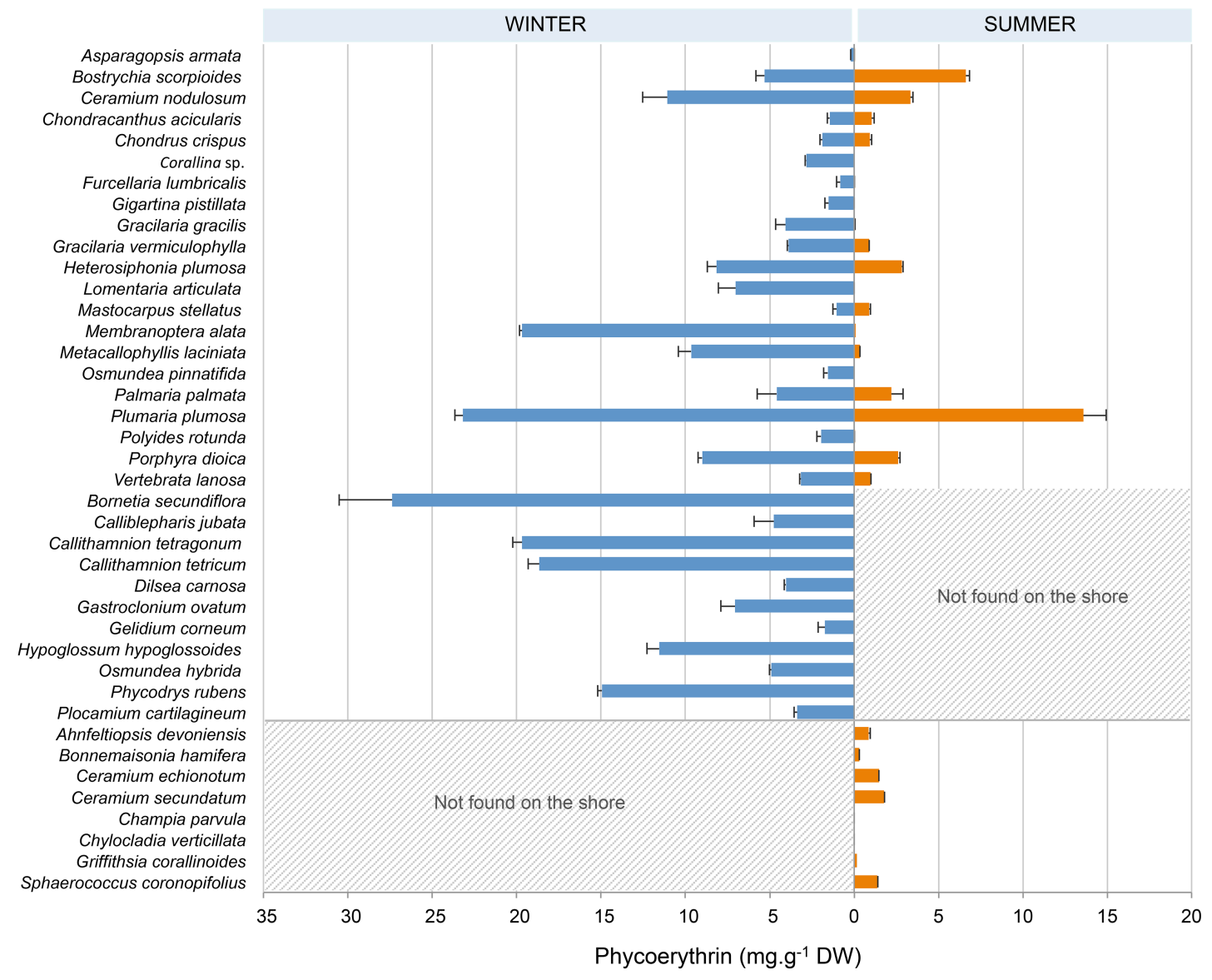


a)

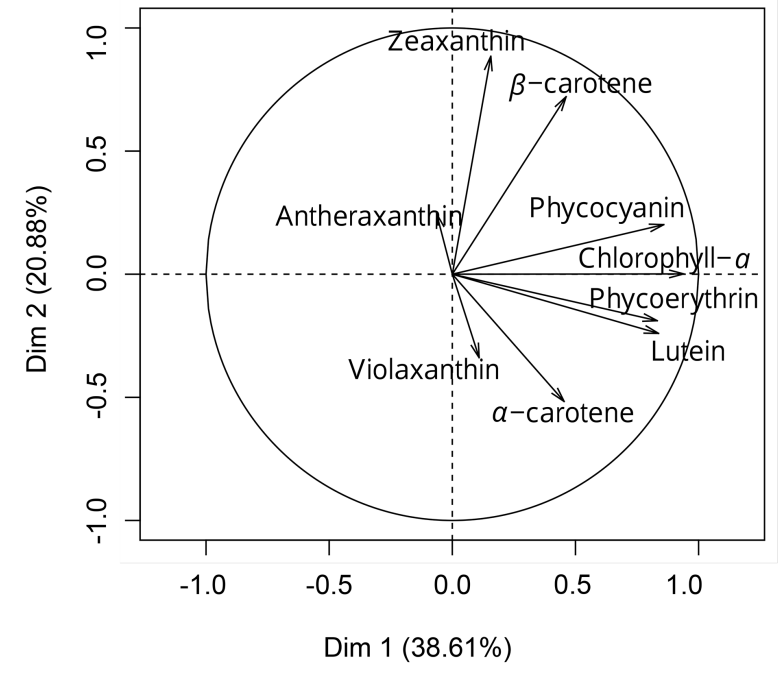

b)

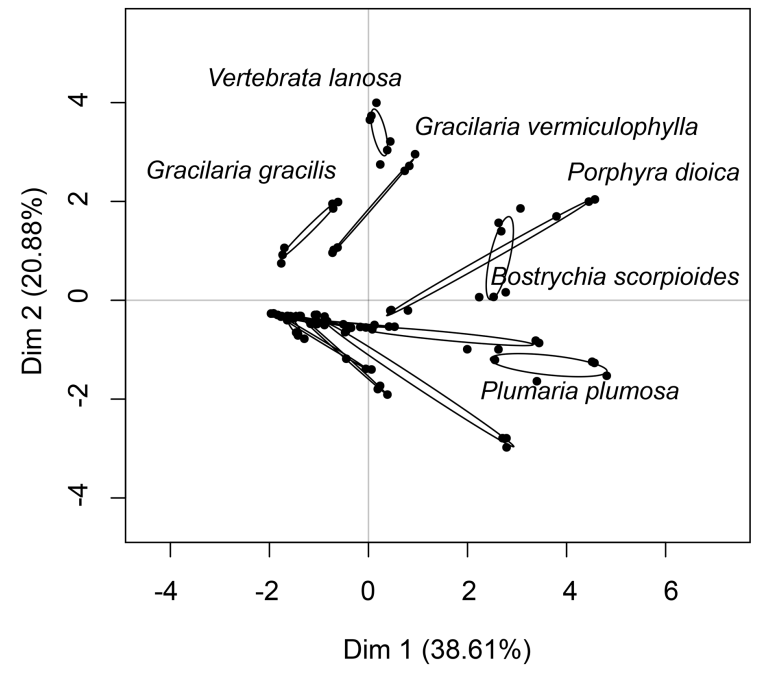




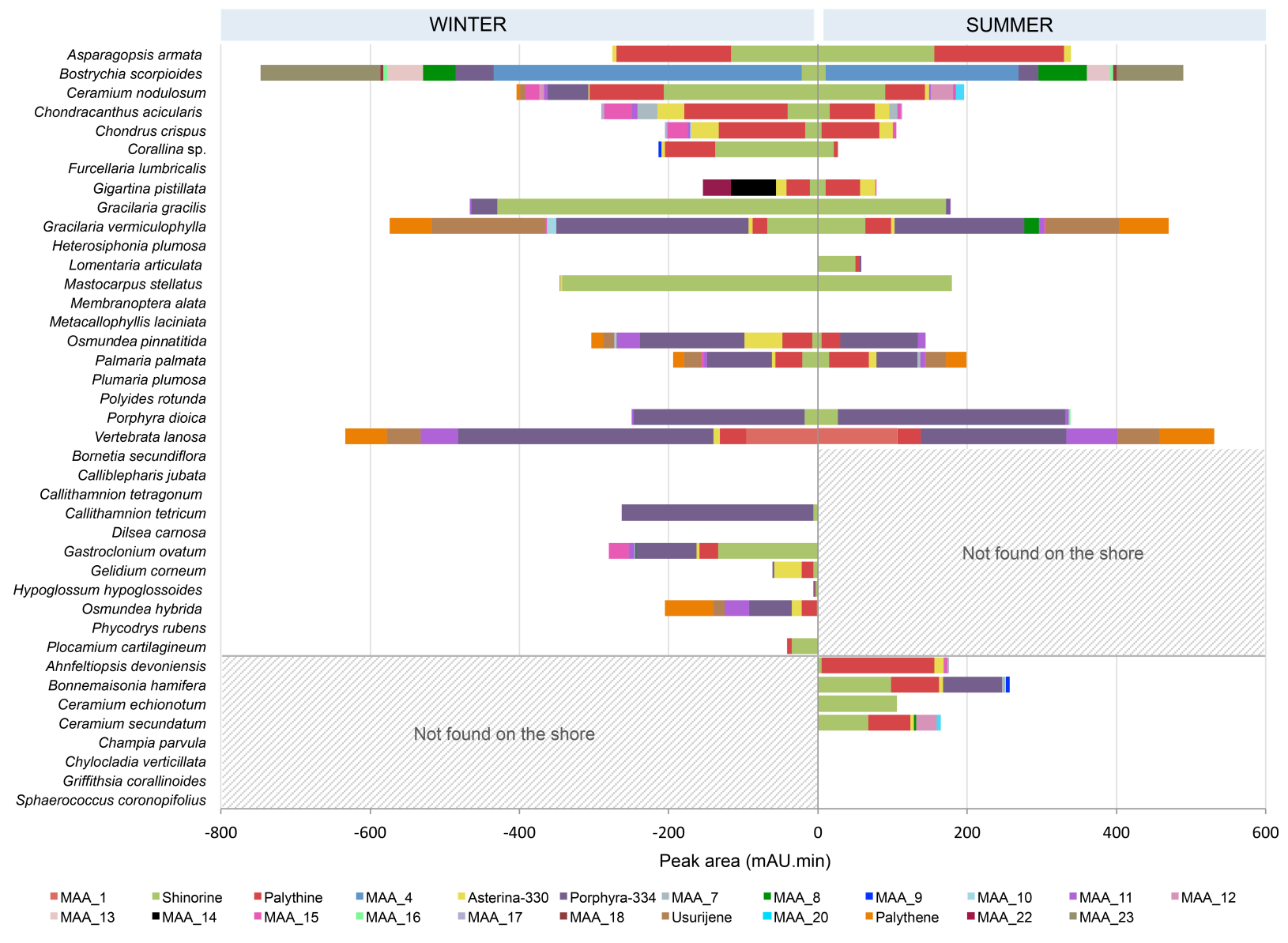




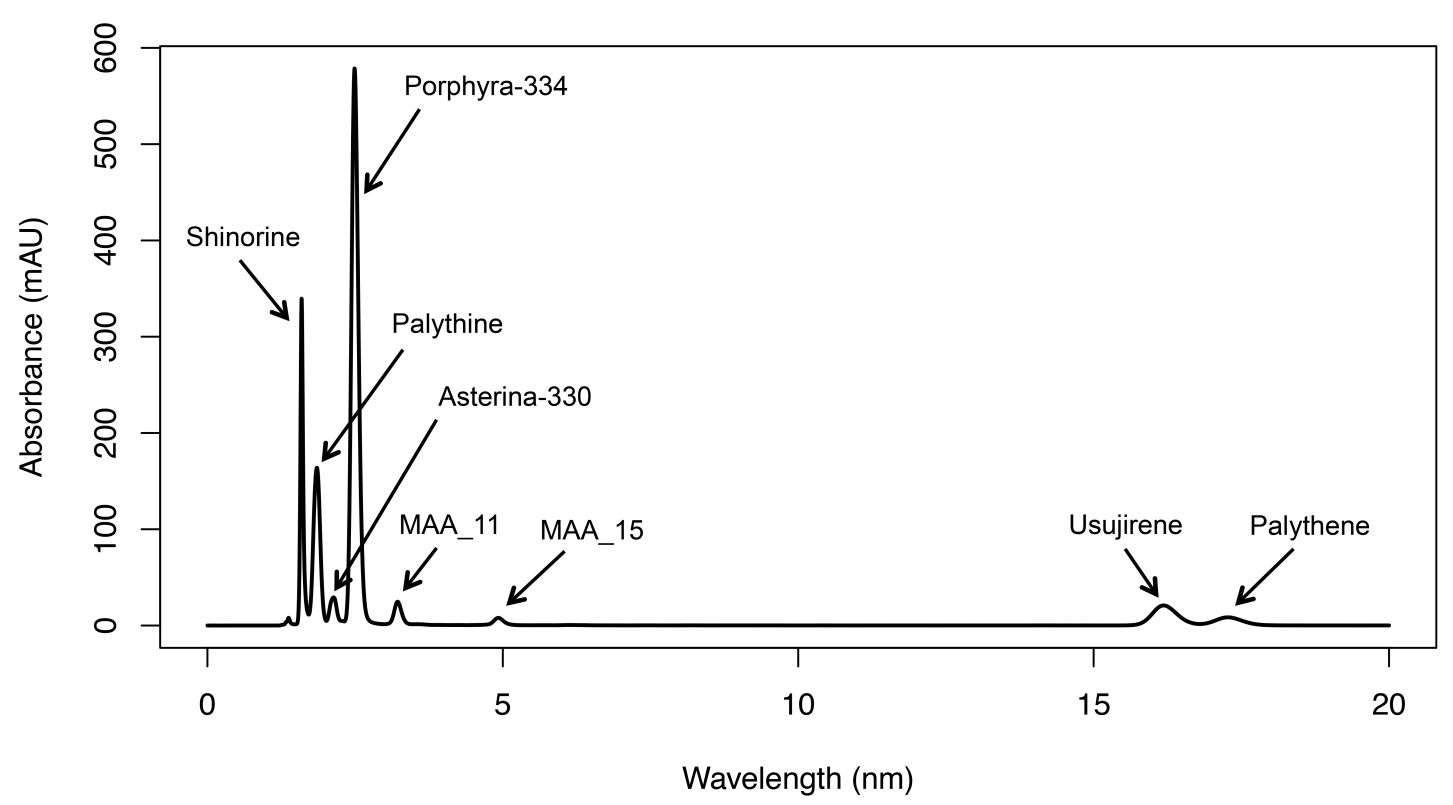


a)

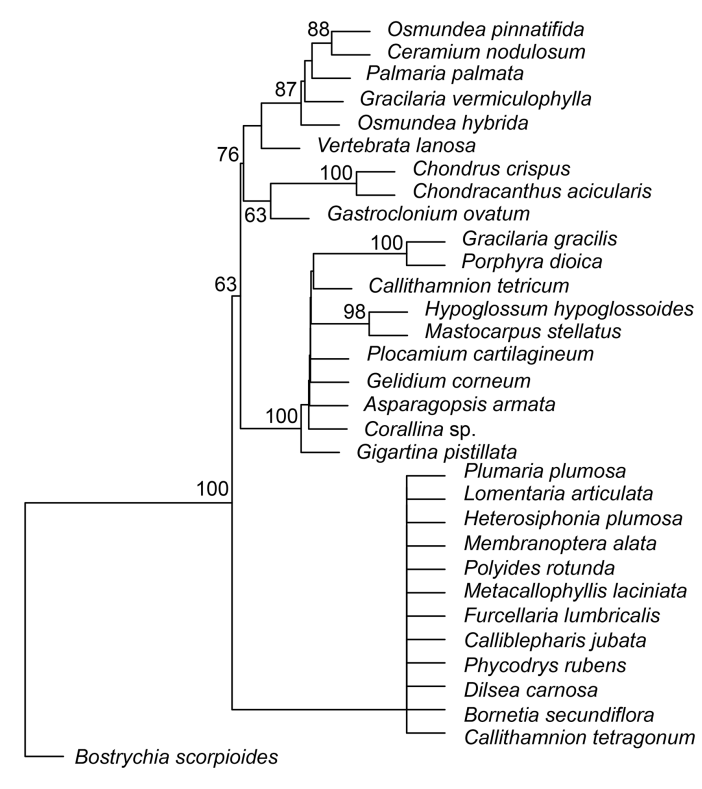

b)

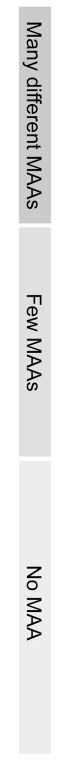

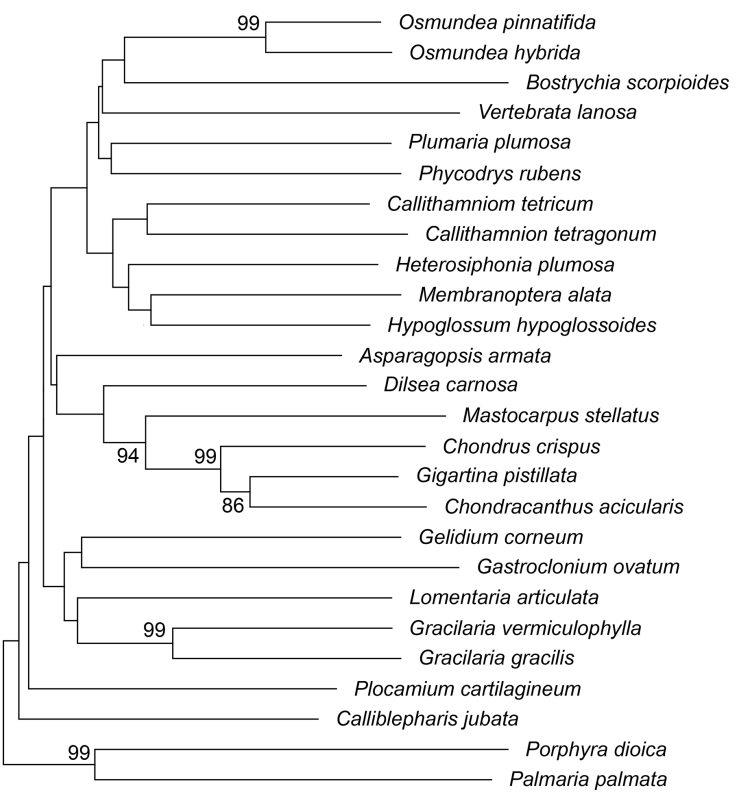


Highlights

- Detection of 23 potential MAAs in 40 Rhodophyta species, including 6 already identified (shinorine, palythine, asterina-330, porphyra-334, usurijene, palythene)

- First report on the MAAs composition for some red seaweeds

- High variability in MAAs content and composition between the different species, with no link with phylogeny, morphology, position on the shore or sampling site

- A MAAs extraction method using 70\% ethanol being less toxic than conventional methanol, and giving potential valorisable extracts 